\title{
Descriptions and phylogenetic relationships of four new species and a new name of Habenaria (Orchidaceae) from the cerrado and campos rupestres of Brazil
}

\author{
João A. N. Batista ${ }^{1}()^{\cdot}$ Karina Proite $^{1} \cdot$ Luciano de Bem Bianchetti $^{2}$
}

Received: 7 September 2016/Accepted: 22 March 2017/Published online: 24 April 2017

(C) Springer-Verlag Wien 2017

\begin{abstract}
Four new orchid species and one variety from the cerrado and campos rupestres of central and southeastern Brazil are described and illustrated: Habenaria brachydactyla, $H$. irwiniana, $H$. minuta, $H$. pansarinii, and H. pansarinii var. minuscula. Habenaria campylogyna is proposed as a new name for the illegitimate $H$. humilis Cogniaux. The five species differ from other Neotropical taxa by being small, slender plants with linear leaves concentrated at the base of the stem. Molecular phylogenetic analyses based on nuclear and plastid DNA sequences revealed that they are not closely related, and do not belong to any of the previously identified Neotropical subclades. All of the new taxa were recovered in isolated positions, branching from basal nodes of larger subclades, suggesting that these morphological characters represent plesiomorphic traits in the Neotropical clade. Habenaria brachydactyla is genetically distinct and represents an early lineage of the Neotropical Habenaria clade. All taxa are considered threatened because of their small numbers of populations with few individuals and/or restricted distributions. Detailed descriptions, photographs, illustrations, notes, and a key to the species are presented.
\end{abstract}

Handling editor: Ricarda Riina.

João A. N. Batista

janb@icb.ufmg.br

1 Departamento de Botânica, Instituto de Ciências Biológicas, Universidade Federal de Minas Gerais, Av. Antônio Carlos 6627, Pampulha, C.P. 486, Belo Horizonte, MG 31270-910, Brazil

2 Parque Estação Biológica, Embrapa Recursos Genéticos e Biotecnologia, Final Av. W5 Norte, C.P. 02372, Brasília, DF 70770-901, Brazil
Keywords Brazil $\cdot$ Cerrado $\cdot$ Habenaria $\cdot$ Molecular phylogenetics $\cdot$ New species

\section{Introduction}

Habenaria Willd. (Habenariinae, Orchideae, Orchidaceae) is a large genus comprising approximately 873 terrestrial species (Govaerts et al. 2016) distributed through tropical and subtropical regions worldwide (Pridgeon et al. 2001a). Brazil, with about 170 species (Batista et al. 2011a, b, 2012, 2016), has the largest number of Habenaria species in the New World and possibly also worldwide. The major treatments of the genus for that country are currently those of Cogniaux (1893) in Flora Brasiliensis, Hoehne (1940) in Flora Brasilica, and Pabst and Dungs (1975) in Orchidaceae Brasilienses. The main centres of diversity of Habenaria in Brazil are in cerrado and campos rupestres vegetation in the central region of that country.

The only worldwide revisions of Habenaria were organized by Kränzlin $(1892,1901)$, who recognized 32 sections. The characterizations of the sections were primarily based on the degrees of dissection of the petals and lips and on gynostemium structure, especially stigma length. For Brazil, Cogniaux (1893) generally followed Kränzlin's sectional characterization in his treatment of Habenaria in Flora Brasiliensis and recognized 12 sections for the country. Batista et al. (2013) recently used DNA sequence data to conduct a phylogenetic analysis of the New World species of the genus. They showed that the Neotropical species formed a monophyletic group (and that all the current sections represented in the Neotropics were paraphyletic or polyphyletic).

In the revision of the genus for the Flora Brasilica, Hoehne (1940) used a different approach and divided the 
Brazilian species into nine informal groups, starting with their vegetative organs and then advancing through details of their flowers. Although the groups proposed by Hoehne were created as artificial subdivisions, they generally agree more with the results of the molecular phylogenetic analyses of the New World species (Batista et al. 2013) than Kränzlin's and Cogniaux's formal sections. Among the groups created by Hoehne, the Humilis group (including $H$. humilis Cogn.) was characterized as comprising small, slender plants with basal, linear, roundish, or lanceolate leaves. Pabst and Dungs (1975) followed the divisions established by Hoehne in their survey of Brazilian orchids in the Orchidaceae Brasiliensis, but further divided some groups called alliances. For example, species with roundish to elliptical leaves were removed from the Humilis group, however, still leaving the remaining species in the Humilis alliance with few morphological similarities between them-raising doubts whether they could form a natural group.

Field and herbarium surveys of Neotropical Habenaria revealed a group of five taxa from Brazil that are characterized as small, slender plants with linear leaves concentrated at the stem base, being morphologically similar to $H$. humilis (the only taxon in the group that we were able to assign to a previously described species). The similarity in vegetative morphology between these taxa suggests they could be related; however, the phylogeny of the group has never been inferred. We investigated here the morphology, diversity, and taxonomy of this group of species. We also performed molecular phylogenetic analyses to verify whether the group was monophyletic and to determine phylogenetic relationships.

\section{Materials and methods}

\section{Taxon sampling for phylogenetic analyses}

The dataset for the phylogenetic analyses consisted of the combined ITS, matK-trn, K and rps16-trnK DNA sequences of 54 terminals of 49 Neotropical Habenaria taxa, plus four African Habenaria species, and Gennaria diphylla Parl. The latter was used as the functional outgroup. This dataset is basically the same used by Pedron et al. (2014) to infer phylogenetic relationships in Habenaria sect. Pentadactylae Kraenzl., although it also includes three of the new species described here $(H$. brachydactyla, $H$. irwiniana, and $H$. pansarinii) as well as H. bicornis Lindl. (Batista et al. 2014). Although the number of species is smaller than the ITS + matK dataset used by us to infer phylogenetic relationships of New World Habenaria (Batista et al. 2013), it includes a selected sample of species encompassing all major subclades of Neotropical Habenaria and 2.6 times more characters. Voucher information, geographic origins, and GenBank accession numbers can be found in Pedron et al. (2014); information concerning the newly sequenced accessions is provided in Table 1.

\section{Molecular markers}

Nucleotide sequences from one nuclear (ITS) and three plastid (matK, trnK intron and rps16-trnK) genome regions were used in the analyses. The ITS region consisted of internal transcribed spacers (ITS1 and ITS2) and the intervening $5.8 \mathrm{~S}$ gene of the nuclear ribosomal multigene family. The plastid DNA regions included the complete sequences of the mat $\mathrm{K}$ gene, part of the upstream and the complete downstream contiguous trnK intron, and the rps16-trnK intergenic spacer. DNA extraction, amplification, and sequencing were carried out as described by Pedron et al. (2014). Bidirectional sequence reads were obtained for all of the DNA regions, and the resulting sequences were edited and assembled using Staden Package software (Bonfield et al. 1995). The edited sequences were aligned with MUSCLE (Edgar 2004), and the resulting alignments were manually adjusted using MEGA4 software (Tamura et al. 2007).

\section{Phylogenetic analyses}

The data were analysed by means of maximum parsimony (MP), maximum likelihood (ML), and Bayesian inference. Because no strongly supported conflicting topologies were detected in our previous analyses with similar datasets (Pedron et al. 2014), only searches performed with the combined matrix are presented and discussed. Phylogenetic analyses using MP were performed using PAUP* version 4 (Swofford 2002) with Fitch parsimony (equal weights, unordered characters; Fitch 1971) as the optimality criterion. Each search consisted of 2000 replicates of random taxon additions, with branch swapping using the tree-bisection and reconnection (TBR) algorithms, saving $\leq 10$ trees per replicate to avoid extensive swapping on suboptimal islands. Internal support was evaluated by character bootstrapping (Felsenstein 1985) using 2000 replicates, simple addition, and TBR branch swapping, saving $\leq 10$ trees per replicate. For bootstrap support levels, we considered bootstrap percentages (BS) of $50-70 \%$ as weak, $71-85 \%$ as moderate, and $>85 \%$ as strong (Kress et al. 2002). We also performed analyses using 10,000 replicates, but the results were the same.

The ML analysis was conducted using the RAxML-HPC version 8 (Stamatakis 2014) as implemented in the Cyberinfrastructure for Phylogenetic Research (CIPRES) Portal 2.0 (Miller et al. 2010). Analysis of 1000 rapid bootstrap replicates (Stamatakis et al. 2008) was followed 
Table 1 Voucher information and GenBank accessions for the new sequences produced for this work

\begin{tabular}{|c|c|c|c|c|c|}
\hline Taxon & Voucher & Origin $^{\mathrm{a}}$ & ITS & mat $\mathrm{K}-t r n \mathrm{~K}$ & $\begin{array}{l}\text { rps16- } \\
\operatorname{trn} \mathrm{K}\end{array}$ \\
\hline Habenaria bicornis Lindl. & L.P. Felix 10803 (EAN) & $\begin{array}{l}\text { Brazil, } \\
\text { PB }\end{array}$ & KF998087 & KX784170 & KX784174 \\
\hline Habenaria brachydactyla J.A.N.Bat. \& Bianch. & $\begin{array}{l}\text { J.A.N. Batista and P. Proite } 3109 \\
\text { (BHCB) }\end{array}$ & $\begin{array}{l}\text { Brazil, } \\
\text { DF }\end{array}$ & KX784176 & KX784171 & KX784175 \\
\hline Habenaria campylogyna J.A.N.Bat. \& Bianch. & J.A.N. Batista 1901 (BHCB) & $\begin{array}{l}\text { Brazil, } \\
\text { MG }\end{array}$ & HM777581 & KJ021364 & KJ021419 \\
\hline Habenaria irwiniana J.A.N.Bat. \& Bianch. & J.A.N. Batista 249 (CEN) & $\begin{array}{l}\text { Brazil, } \\
\text { GO }\end{array}$ & HM777642 & KX784167 & KX784172 \\
\hline Habenaria pansarinii J.A.N.Bat. \& Bianch. & J.A.N. Batista et al. 1926 (BHCB) & $\begin{array}{c}\text { Brazil, } \\
\text { MG }\end{array}$ & HM777520 & KX784168 & KX784173 \\
\hline $\begin{array}{l}\text { Habenaria pansarinii var. minuscula J.A.N.Bat. \& } \\
\text { Bianch. }\end{array}$ & J.A.N. Batista et al. 2838 (BHCB) & $\begin{array}{l}\text { Brazil, } \\
\text { MG }\end{array}$ & HM777521 & KX784169 & - \\
\hline
\end{tabular}

Voucher information and GenBank accession numbers for other terminals are the same as in Pedron et al. (2014), where H. campylogyna is identified as $H$. humilis. An en-dash denotes missing data

${ }^{a}$ Abbreviations for Brazilian states: $G O$ Goiás; $M G$ Minas Gerais; $P B$ Paraíba, $D F$ Federal District

by a search for the tree that maximizes the likelihood function, with the default value of 25 rate categories and the estimation of all free model parameters for five character partitions (ITS region, matK, $\operatorname{trnK} 5^{\prime}$ intron, trnK $3^{\prime}$ intron, and rps16-trnK intergenic spacer). Both the bootstrap searches and the search for the ML tree used the GTRGAMMA model for nucleotides.

Bayesian analysis was conducted using MrBayes version 3.1.2 (Ronquist et al. 2005) as implemented in the Cyberinfrastructure for Phylogenetic Research (CIPRES) Portal 2.0 (Miller et al. 2010), treating each DNA region (ITS region, $m a t \mathrm{~K}, \operatorname{trn} \mathrm{K}$ intron, $r p s 16-t r n \mathrm{~K}$ ) as a separate partition. An evolutionary model for each DNA region was selected using the Akaike information criterion (AIC) in MrModeltest 2 (Nylander 2004). The selected models were the same as described in Pedron et al. (2014). The unlink command was used to unlink parameters among each partition. Each analysis consisted of two independent runs, each with four chains, for 10,000,000 generations, sampling one tree every 1000 generations. Convergence between the runs was evaluated using the average standard deviation of split frequencies $(<0.01)$ and was achieved after 160,000 generations. After discarding the first 2500 trees $(25 \%)$ as the burn-in, the remaining trees were used to assess topology and posterior probabilities (PPs) in a majority-rule consensus. Posterior probabilities (PPs) in Bayesian analysis are not directly comparable to bootstrap percentages, generally being much higher (Erixon et al. 2003). We therefore used criteria similar to a standard statistical test, considering groups with PPs $>0.95$ as strongly supported, groups with PPs ranging from 0.90 to 0.95 as moderately supported, and groups with PPs $<0.90$ as weakly supported.

\section{Morphological, taxonomic, and conservation status analyses}

The habit and perianth were examined and illustrated from liquid-preserved or dry herbarium material, while the gynostemium was examined from liquid-preserved material, using a stereoscopic microscope, and measured using a digital calliper. Data concerning flowering times, habitat, and distribution were based on herbarium labels and field observations. Morphological terminology is based on Stearn (1992) and Simpson (2006). Specimens were searched in 69 herbaria in Brazil, Europe, and the USA, and were found and examined in: AMES, BHCB, BHZB, CEN, ESA, G, HB, HBG, HEPH, HUEFS, IAN, K, M, MBM, NY, OUPR, P, R, RB, RENZ (images), S, SP, SPF, UB, UEC, and UFG, acronyms following Thiers (2015). Estimation of extent of occurrence and area of occupancy were performed using a beta version of GeoCAT (Bachman et al. 2011) as implemented in the Royal Botanic Gardens, Kew Web site. Conservation status was inferred using the World Conservation Union Red List Categories and Criteria (IUCN 2012) and the guidelines for using the IUCN red list categories and criteria (IUCN 2016).

\section{Results}

The matrix with the combined ITS, complete matK gene, part of the $\operatorname{trn\mathrm {K}}$ intron, and the rps16-trnK intergenic spacer consisted of 3658 aligned characters, of which 320 (8.7\%) were parsimony informative. Missing data accounted for $7.4 \%$ of the combined matrix, of which $5.8 \%$ were from the complete mat K-trnK and rps 16-trnK 
sequences that were missing from Old World taxa. Missing data for the Neotropical sequences accounted for just $1.6 \%$ of the combined matrix. The parsimony analysis retained the 10 most parsimonious trees, with a tree length of 1034 steps, consistency index (CI) of 0.72 , and a retention index (RI) of 0.79 . Table 2 shows the data matrix values from the individual or combined datasets, with tree statistics and other parameters of the parsimony analyses. The strict consensus tree from parsimony analysis was for the most part congruent with the Bayesian majority-rule consensus tree and ML best tree, except for the position of the African species $H$. tridens Lindl., which was recovered inside the Neotropical clade as sister to the New World species excluding $H$. brachydactyla, but with low support $(58 \%$ BS-MP). Other relationships were similar to the Bayesian and ML analyses. The Bayesian majority-rule consensus tree was chosen for presentation here because it was more fully resolved and had stronger overall support (Fig. 1). The relationships recovered in the Bayesian and ML analyses were similar to those of our previous molecular phylogenetic studies (Batista et al. 2013, 2014; Pedron et al. 2014), with the New World Habenaria species forming a monophyletic group that was sister to $H$. tridens (1.00 PP, 100\% BS-ML). Habenaria brachydactyla was recovered as sister to the remaining species of the New World clade, although with only low to moderate support (0.83 PP, 80\% BS-ML). Several well-supported subclades were recovered within the New World clade (Fig. 1) that corresponded to the same subclades identified in our previous analyses (Batista et al. 2013, 2014; Pedron et al. 2014), and are numbered accordingly (subclades 1-21). The relationships between the subclades were similar to our previous results, except for $H$. pratensis (Salzm. ex Lindl.) Rchb.f. (subclade 1), which was recovered with high support (1.00 PP, 87\% BS-ML, 82\% BS-MP) as sister to a clade formed by subclades 11-21. H. pansarinii was recovered in all of the analyses with high to moderate support (1.00 PP, 83\% BS-ML, 75\% BS-MP) as sister to a basal subclade formed by subclades 2-6 plus $H$. bicornis, H. leucosantha Barb.Rodr., H. macilenta (Lindl.) Rchb.f., and $H$. regnellii Cogn. Habenaria campylogyna was sister (1.00 PP, 77\% BS-ML, 61\% BS-MP) to a subclade formed by $H$. caldensis Kraenzl. $+H$. balansae Cogn. $+H$. melanopoda Hoehne \& Schltr., whereas $H$. irwiniana was sister (1.00 PP, 99\% BS-ML, 94\% BS-MP) to a subclade comprising $H$. ayangannensis Renz and subclades 16-21 (1.00 PP, 100\% BS-ML, 98\% BS-MP).

\section{Discussion}

Despite the morphological similarities of the habits of $H$. brachydactyla, $H$. irwiniana, $H$. pansarinii, and $H$. campylogyna, they are distantly related phylogenetically. Interestingly, each of the four species was recovered at the basal node of a main clade in the phylogeny. In other orchid groups, morphological characters present in taxa branching out from basal nodes have been interpreted as plesiomorphic, such as the bifoliate pseudobulbs in Neotropical Bulbophyllum Thouars (Smidt et al. 2011), the conduplicate leaves in Malaxideae (Cameron 2005), the absence of articulation between the ovary and pedicel between Dilomilis Raf. plus Neocogniauxia Schltr., and Pleurothallidinae (Pridgeon et al. 2001b), the epiphytic habit in Galeandra Lindl. (Monteiro et al. 2010), and pseudobulbs with many leaves and rounded in cross section in the Cyrtochilum Kunth clade (Williams et al. 2001). In our case of study, this phylogenetic pattern could indicate that the common set of morphological characters exhibited by these four Habenaria species (small, slender plants with linear leaves concentrated at the base of the stem) represent plesiomorphic traits in the Neotropical clade. A few Asian species of the genus, such as $H$. khasiana Hook.f. (= $H$. graminea Lindl.), $H$. rosulata Ames, and $H$. viridiflora (Rottler ex Sw.) R.Br. ex Spreng., share the same set of morphological characteristics (i.e. small, slender plants with linear or narrowly lanceolate leaves concentrated at the base of the stem). Of these, only $H$. viridiflora had been included in a molecular phylogenetic analysis, where it was strongly supported as sister to Pecteilis sagarikii Seidenf.

Table 2 Data matrix values and tree statistics for the parsimony analyses

\begin{tabular}{llcccccccc}
\hline & Terminals & $\begin{array}{l}\text { Aligned } \\
\text { length }\end{array}$ & $\begin{array}{l}\text { Missing } \\
\text { data }(\%)\end{array}$ & $\begin{array}{l}\text { Variable, non- } \\
\text { informative sites }\end{array}$ & $\begin{array}{l}\text { Parsimony } \\
\text { informative } \\
\text { sites (\%) }\end{array}$ & Trees & $\begin{array}{l}\text { Fitch tree } \\
\text { length }\end{array}$ & $\begin{array}{l}\text { Consistency } \\
\text { index (CI) }\end{array}$ & $\begin{array}{l}\text { Retention } \\
\text { index (RI) }\end{array}$ \\
\hline ITS & 53 & 745 & 0.2 & 116 & $144(19.3)$ & 17,040 & 440 & 0.75 \\
matK-trnK & 53 & 1946 & 8.2 & 120 & $107(5.5)$ & 18,460 & 326 & 0.78 & 0.76 \\
rps 16-trnK & 47 & 967 & 11.2 & 83 & $69(7.1)$ & 11,380 & 228 & 0.72 & 0.87 \\
Plastid & 53 & 2913 & 9.2 & 203 & $176(6.0)$ & 12,130 & 567 & 0.74 & 0.83 \\
Combined & 53 & 3658 & 7.4 & 319 & $320(8.7)$ & 10 & 1034 & 0.72 & 0.79 \\
\hline
\end{tabular}


Fig. 1 Bayesian 50\% majorityrule consensus tree of the combined nuclear (ITS) and plastid (matK, trnK intron, rps 16-trnK) datasets. Numbers next to the nodes are posterior probabilities $(P P)$ from the Bayesian analysis and bootstrap percentages $(B S)$ from the maximum likelihood and parsimony analyses, respectively. Values are shown only for selected clades. Bootstrap percentages $\leq 50 \%$ or different topologies in other analyses are indicated by an endash (-). Neotropical subgroups are numbered according to Batista et al. (2013). The new species and new name proposed here are highlighted in bold

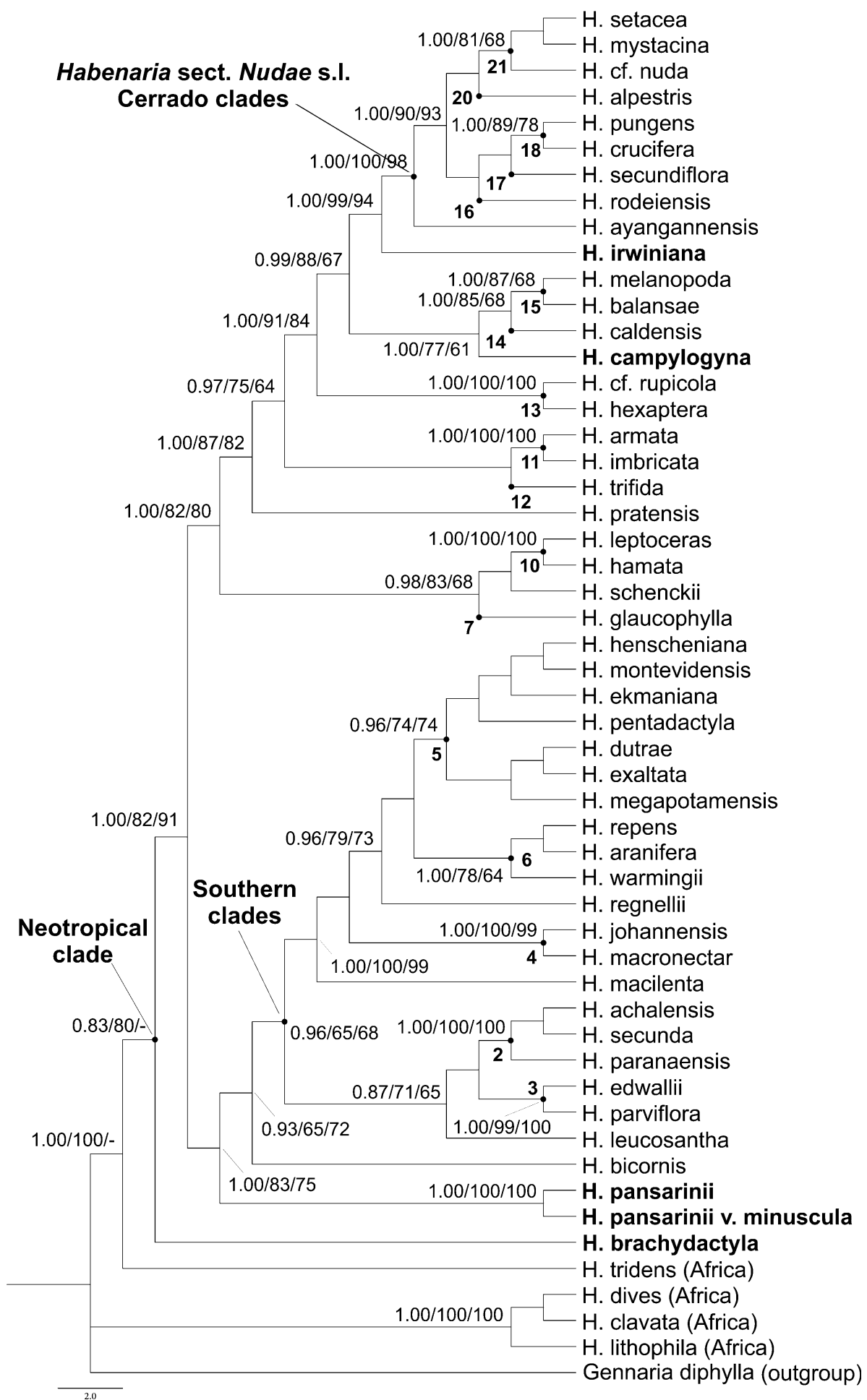

(Inda et al. 2012), a species with large, ovate-elliptical leaves (Seidenfaden 1977); both were, in turn, placed in a large polytomy. Determining the placement of these species in more densely sampled and better resolved phylogenies would provide further insights into the evolution of morphological characters in the genus.
The position of Habenaria brachydactyla was not resolved. It was recovered as sister to the remaining Neotropical species in the Bayesian and ML analyses, whereas it was sister to a clade formed by $H$. tridens, from Africa, plus the remaining Neotropical species in the parsimony analyses-but with low support in both cases- 
indicating that its relationships are not yet clear. The $H$. brachydactyla sequences have many autapomorphies and are quite distinct from other Neotropical species (which show only very low sequence divergence) (Batista et al. 2013), so that species may represent an early lineage of the Neotropical Habenaria clade. Compared to other large orchid genera with pantropical distribution, the phylogenetic position of $H$. brachydactyla is unusual. In Bulbophyllum (Smidt et al. 2011) and Vanilla Plum. ex Mill. (Bouetard et al. 2010), groups stemming from basal nodes are formed by a set of species, which share a common geographic distribution and morphology. In other genera such as Polystachya Hook. (Russell et al. 2010), Malaxis Sol. ex Sw. and Liparis Rich. (Cameron 2005), sampling is low or the number of New World species is small for any inferences in this respect. Habenaria brachydactyla is restricted to central Brazil and grows as an aquatic plant, with its leaves completely submerged, an apparently unique feature among New World species of the genus. Habenaria tridens, the closest African relative to the Neotropical clade sampled, occurs along streambanks, often with the roots submerged (Linder and Kurzweil 1999). This similarity suggests that the ancestor of the Neotropical species was an aquatic species, though any conclusion in this sense will depend on a larger sampling of African species and on the resolution of the base of the phylogeny of the Neotropical clade. Our results showed the unique nature of this species (which is also ecologically distinct from other Neotropical species) and indicated that additional studies will be necessary to determine and understand its exact relationship with other New World species.

Habenaria pansarinii was highly to moderately supported as sister to a clade formed by subclades $2-6$ and $H$. bicornis, $H$. leucosantha, $H$. macilenta, and $H$. regnellii. Most species in this large clade (approximately 45 species) are characterized as medium-sized to tall, usually robust, leafy plants, with broad, patent leaves that are commonly spread along the stem. Additionally, species in subclades 2-6 are concentrated in southern Brazil and southern South America (Southern clades in Fig. 1), although a few species, such as $H$. repens Nutt., have broad distributions or occur in central and northern South America. The inclusion of $H$. pansarinii, with high support and at a basal node in this clade, is intriguing as it does not share any similarities in its morphology, ecological preferences, or geographic distribution with other species or subclades of the group.

Habenaria irwiniana was highly supported as sister to a clade comprising $H$. ayangannensis and subclades 16-21. These subclades comprise a large group of about 54 species named Cerrado clades by Batista et al. (2013), because they are primarily Brazilian and mostly concentrated in the cerrado and campos rupestres of the central and south-eastern regions of that country. Additionally, most species in these subclades have linear, grass-like leaves that are commonly appressed to the stem, and belong to a broad concept of Habenaria sect. Nudae Cogn. The basal position of $H$. irwiniana in this lineage suggests sympatric and allopatric speciation of this group from a $H$. irwiniana-like ancestor in the cerrado and campos rupestres of central and southeastern Brazil. The isolated position of H. irwiniana in the phylogenetic trees also reinforces its morphological distinctiveness from other Neotropical species. Habenaria minuta was not sampled in the molecular phylogenetic analysis but is morphologically similar to $H$. irwiniana, and probably closely related to the latter species.

The infrageneric classification of $H$. campylogyna $(=H$. humilis Cogn.) has been controversial. Cogniaux (1893) included the species in $H$. sect. Pentadactylae, a heterogeneous assemblage of 34 species comprising the largest Neotropical section of the genus (Kränzlin 1901); Hoehne (1940) placed the species in the Humilis group; Pabst (Pabst and Dungs 1975) included it in the Humilis Alliance, which has a different circumscription and species composition. The molecular phylogenetic analysis of Pedron et al. (2014) indicated that $H$. sect. Pentadactylae was polyphyletic. To make the section monophyletic, these authors excluded 31 species, including $H$. humilis - but the phylogenetic and morphological relationships of this species were not discussed.

In our analyses, we recovered $H$. campylogyna as sister to a clade formed by $H$. caldensis $+H$. balansae $+H$. melanopoda. In the molecular phylogenetic analysis of New World Habenaria (Batista et al. 2013), this clade also included $H$. magniscutata Catling as sister to $H$. caldensis with high support. The only group in this clade that makes some sense in terms of morphological relationships is the one formed by $H$. balansae $+H$. melanopoda and related species, which are very similar (Batista et al. 2013). There are no apparent morphological similarities, however, between members of this subclade, $H$. campylogyna, $H$. caldensis, and $H$. magniscutata, which are also very distinct from each other (Batista et al. 2013; Carvalho et al. 2013). On the other hand, there is some geographic and ecological structure in this clade, as for $H$. campylogyna, $H$. magniscutata, and $H$. caldensis, which are restricted to campos rupestres. All three species occur (and are commonly sympatric) in the Espinhaço Range of Minas Gerais state (Munhoz 2007), whereas the latter two also occur sympatrically in the highlands of Central Brazil (Munhoz and Proença 1998; Batista et al. 2004) and the Serra da Canastra Range (Carvalho et al. 2013). 


\section{Taxonomic treatment}

Key to the Brazilian Habenaria, as slender, delicate plants, with linear leaves concentrated at the base of the stem

1a. Petals simple or anterior segment inconspicuous, 0.3-0.5 mm long; lip simple or with inconspicuous lateral segments, $0.3-0.6 \mathrm{~mm}$ long .......... H. brachydactyla

1b. Petals bipartite, anterior segment 1.1-6.0 mm long; lip tripartite, lateral segments $1.5-8.0 \mathrm{~mm}$ long ........ 2

2a. Leaves 35-105 mm long; pedicellate ovary 13-19 mm long; lip undivided at base 1.5-3.0 mm long; anther canals 1.8-2.5 mm long; stigmatophores parallel, separate, $2.3-2.5 \mathrm{~mm}$ long; hemipollinaria separate; restricted to the Espinhaço Range in Minas Gerais state

H. campylogyna

2b. Leaves 6-55 mm long; pedicellate ovary 5.4-15.0 mm long; lip undivided at base $0.5-1.1 \mathrm{~mm}$ long; anther canals $0.15-0.3 \mathrm{~mm}$ long; stigmatophores closely parallel, closely spaced, $0.8-2.0 \mathrm{~mm}$ long; hemipollinaria joined by the viscidia ......................... 3

3a. Spur clavate or linear, 5-15 $\mathrm{mm}$ long; restricted to the highlands of central Brazil in Goiás state and the Federal District.................................. 4

3b. Spur saccate 1.2-3.8 mm long; restricted to the Espinhaço Range of Minas Gerais ......................... 5

4a. Stem, including the inflorescence, $10-22 \mathrm{~cm}$ long; leaves $8-50 \times 1.5-2.0 \mathrm{~mm}$; pedicellate ovary $8-15 \mathrm{~mm}$ long; lip median segment 3.0-5.0($6.0) \times 0.8(-1.0) \mathrm{mm}$; spur $8-15 \mathrm{~mm}$ long, deflexed to curved forward

H. irwiniana

4b. Stem, including the inflorescence, $6-14 \mathrm{~cm}$ long; leaves $6-9 \times 1.0-1.5 \mathrm{~mm}$; pedicellate ovary $7-9 \mathrm{~mm}$ long; lip median segment $2.3-2.8 \times 0.8 \mathrm{~mm}$; spur $5-7 \mathrm{~mm}$ long, reflexed, forming a right angle with the pedicellate ovary; restricted to Chapada dos Veadeiros in Goiás state ............................... H. minuta

5a. Leaves $\quad 15-55 \times 2-5 \mathrm{~mm}$; lateral sepals $2.9-3.7 \times 1.2-1.5 \mathrm{~mm}$; anterior petal segment 3.6-5.4 mm, 1.3-1.6 times as long as the posterior segment; lip lateral segments $3.5-5.4 \mathrm{~mm},(0.9-)$ 1.0-1.3 times as long as the median segment; spur 2.3-3.8 mm, 0.4-0.6 times as long as the pedicellate ovary

H. pansarinii

5b. Leaves $8-26 \times 1-4 \mathrm{~mm}$; lateral sepals $2.2-3.1 \times$ $1.0-1.4 \mathrm{~mm}$; anterior petal segment $1.1-2.5 \mathrm{~mm}, 0.5-0.9$ times as long as posterior segment; lip lateral segments $1.5-2.2 \mathrm{~mm}, 0.8-0.9$ times as long as median segment; spur 1.2-1.4 mm, 0.1-0.2 times as long as the pedicellate ovary

H. pansarinii var. minuscula
Habenaria brachydactyla J.A.N.Bat. \& Bianch., sp. nov.TYPE: Brazil, Federal District, Brasília, Mansões Setor Park Way-MSPW, campo as margens do Córrego do Cedro, na altura em que este é cortado pela pista, próximo a quadra 16 , $15^{\circ} 53^{\prime} \mathrm{S}, 47^{\circ} 56^{\prime} \mathrm{W}, 1045 \mathrm{~m}$ a. s. 1., 2 Jan 2011 (fl.), J.A.N. Batista and P. Proite 3109 (holotype: BHCB 151383!; isotypes: CEN!, MBM, RB, SP) (Figs. 2, 3).

Etymology: From the Greek brachy (short) and dactyl (finger), referring to the short lateral segments of the petals and lip.

Habit and size similar to $H$. irwiniana, but distinct by the very short lateral segments of the petals and lip, (0.0-)0.3-0.6 mm long, large rostellum, $1.4 \times 1.3 \mathrm{~mm}$, anther canals parallel and directed forward, and hemipollinaria separate.

Aquatic to semi-aquatic slender herb. Tuberoid root not examined. Roots few, one per knot, base light green, apex white, up to $4 \mathrm{~cm}$ long, $0.7-1.0 \mathrm{~mm}$ wide, hairy, hairs short, $0.4-1.0 \mathrm{~mm}$ long. Stem erect, $14-28 \mathrm{~cm}$ long including the inflorescence, $0.8-1.5 \mathrm{~mm}$ wide. Leaves $2-4$, one per knot, spreading, largest at the base of the stem, linear-lanceolate, narrow, $1.4-5.0 \times 0.2-0.5 \mathrm{~cm}$; sheathlike leaves along the stem $2-3,0.5-1.0 \mathrm{~cm}$ long. Inflorescence (1.4-)2.5-10.0 cm long, few-flowered, lax; floral bracts oblong, subcaudate, $3-8 \times 2-3 \mathrm{~mm}$, shorter than the pedicellate ovary. Flowers (1-)2-6, green; pedicellate ovary mostly parallel to the rachis, $11-15 \mathrm{~mm}$ long; ovary slightly curved, $10-12 \mathrm{~mm}$ long; pedicel $2-3 \mathrm{~mm}$ long. Sepals green, margins smooth; dorsal sepal concave, when flattened ovate, $3.0-4.0 \times 2.5-3.0 \mathrm{~mm}$; lateral sepals obliquely elliptical, obtuse or subacute, deflexed, $3.5-4.0 \times 1.2-1.5 \mathrm{~mm}$. Petals simple to discreetly bipartite, light green; posterior segment ovate to triangular, slightly falcate, $3.0-3.3 \times 1.0 \mathrm{~mm}$, acute, adherent to the dorsal sepal; anterior segment absent or reduced to a toothlike projection, inserted at the base of the posterior segment, (0.0-)0.3-0.5 mm long, shorter than the posterior segment. Lip simple to discreetly tripartite, green; undivided basal part obscure or absent, $0.5 \mathrm{~mm}$ long; lateral segments deflexed, linear, 0.3-0.6 mm long, shorter than the median segment; median segment linear, straight, $2.0-3.0 \times 0.8 \mathrm{~mm}$; spur deflexed or slightly curved frontwards, free from the bracts, linear, shorter than the pedicellate ovary, $9.0-11.0 \times 0.8 \mathrm{~mm}$, green. Gynostemium erect, $1.8-2.0 \mathrm{~mm}$ high; connective emarginate, green; lateral appendages (auricles) fleshy, verrucose, 0.7-1.0 $\times 0.4 \mathrm{~mm}$, obtuse. Anther bilocular, loculi parallel, $1.0-1.2 \mathrm{~mm}$ high, canals short, $0.5-0.7 \mathrm{~mm}$ long; hemipollinaria separate; viscidia $0.15 \times 0.1 \mathrm{~mm}$, spaced $1 \mathrm{~mm}$ apart; caudicles $0.7 \mathrm{~mm}$ long. Stigmatophores (stigma lobes) 2, closely parallel, together or slightly 
Fig. 2 Habenaria

brachydactyla: a habit; b leaf;

c flower, front view; $\mathbf{d}$ dissected perianth; e petal, variant; f labellum, variant; $\mathbf{g}$ pedicellate ovary, gynostemium, and spur, lateral view (a-d, $\mathbf{g}$ from Batista 156 (CEN); e from Bove et al. 655 (CEN); f from Maury $317(\mathrm{HEPH}))$. Drawn by Maria Helena Burian

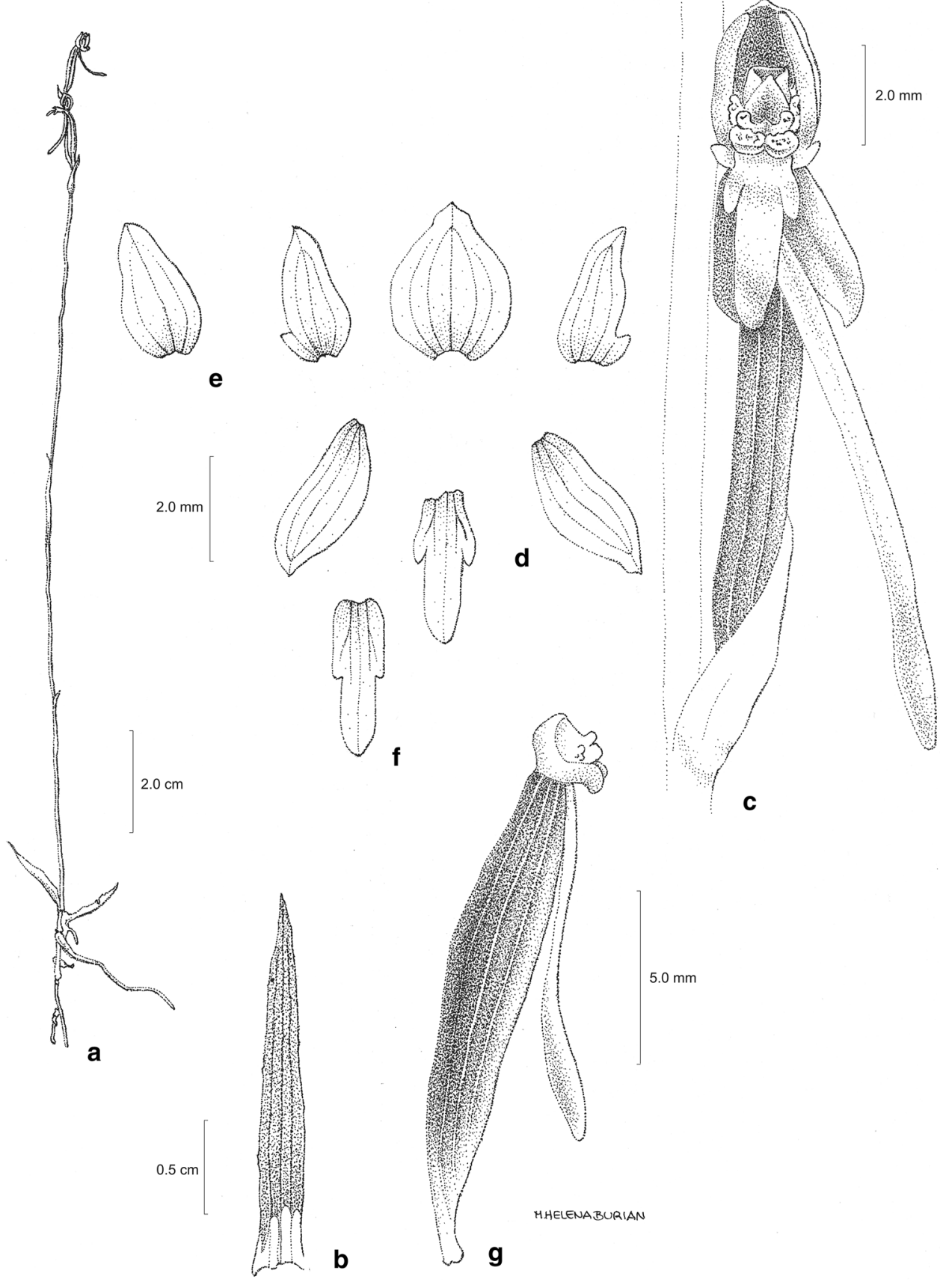

separate, light green, $1.3 \mathrm{~mm}$ long, receptive surface convex, turned frontwards, $0.6-0.8 \mathrm{~mm}$ long, apex $0.7 \mathrm{~mm}$ wide, truncate. Rostellum $1.4 \mathrm{~mm}$ long, light green; midlobe triangular, fleshy, subacute or obtuse, erect, completely placed between the anther loculi or partially projected beyond the loculi, $1 \mathrm{~mm}$ long, $1.3 \mathrm{~mm}$ high; sidelobes parallel, $0.4-0.5 \mathrm{~mm}$ long.

Phenology: Flowering occurs from the beginning to the peak of the rainy season, from November to January
(Table 3). Different from other grassland species of the genus, seasonal brush fires probably do not commonly influence flowering in $H$. brachydactyla because fire very rarely occurs in the habitats where it grows. In the Federal District, the species is sympatric with $H$. parviflora Lindl. and $H$. pubidactyla subsp. brasiliensis J.A.N.Bat. \& Bianch. and flowers at about the same time.

Habitats: Habenaria brachydactyla grows in permanently wet grasslands or in standing water at the margins of ponds 

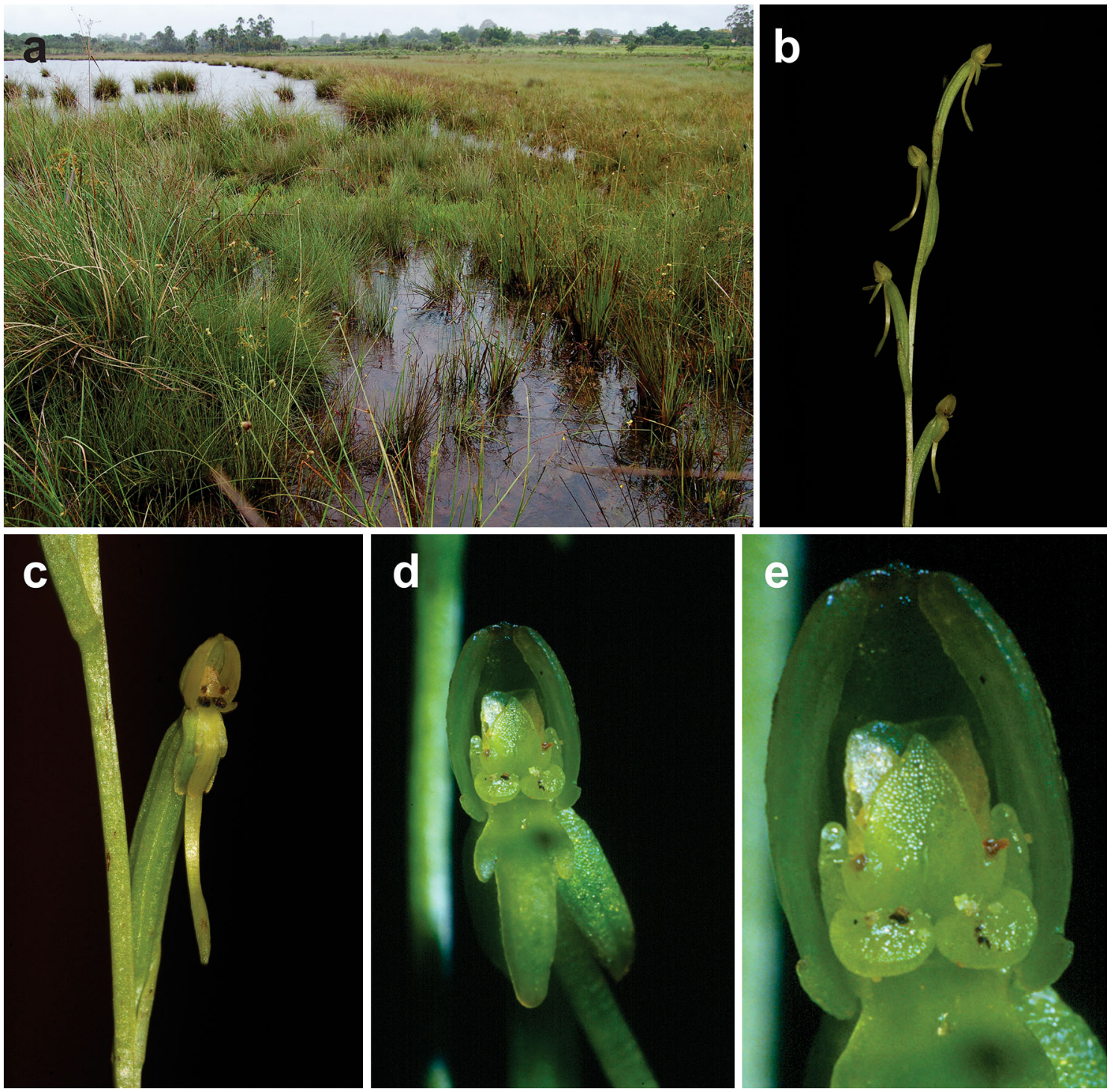

Fig. 3 Habenaria brachydactyla: a habitat, permanently wet grassland at pond edges (Mansões Setor Park Way, Brasília, Federal District; January 2011); b inflorescence; c flower, 3/4 lateral view; d flower, front view; e gynostemium, front view (b, c from Batista and Proite 3109 (BHCB); d, e from Batista 156 (CEN)). Photographs by J.A.N. Batista

Table 3 Number of collections of Habenaria species per month

\begin{tabular}{|c|c|c|c|c|c|c|c|c|c|c|c|c|c|}
\hline \multirow[b]{2}{*}{ Taxa } & \multicolumn{7}{|c|}{ Rainy season } & \multicolumn{5}{|c|}{ Dry season } & \multirow[b]{2}{*}{ Total } \\
\hline & Oct & Nov & Dec & Jan & Feb & Mar & Apr & May & Jun & Jul & Aug & Sep & \\
\hline H. brachydactyla & & 2 & 1 & 2 & & & & & & & & & 7 \\
\hline H. campylogyna & & & 4 & 10 & 16 & 7 & & & & & & & 38 \\
\hline H. irwiniana & & & 1 & 18 & 13 & & & & & 1 & & & 33 \\
\hline H. minuta & & & 1 & 1 & 1 & & & & & & & & 3 \\
\hline H. pansarinii var. pansarinii & & & & & 5 & 3 & & & & & & & 8 \\
\hline H. pansarinii var. minuscula & & & & & & 2 & 2 & 1 & & & & & 5 \\
\hline
\end{tabular}

The rainy and dry season periods presented here refer to central and south-eastern Brazil. Total includes all known records of the taxon

and lakes, in dark, hydromorphic soils, at 700-1300 m a. s. 1. In two collections, the plants were completely submerged, with just the inflorescences appearing above surface. The habitat of $H$. brachydactyla is unique among Neotropical Habenaria species, although other orchid species (such as $H$. parviflora, $H$. pubidactyla subsp. 
brasiliensis and Cyrtopodium parviflorum Lindl.) are sympatric and occur in proximate or associate habitats.

Distribution area: Restricted to the Cerrado biome, and so far known only from the states of Goiás (Serra dos Pirineus and Caiapônia) and Bahia (Barreiras) and the Federal District.

Additional specimens examined: Brazil. Distrito Federal: RA VIII-Núcleo Bandeirante, Setor Mansões Park Way, campo ao lado do Córrego do Cedro um pouco antes do conjunto 1 da Quadra 19, 17 Dec 1996 (fl.), J.A.N. Batista 641 (CEN!); Águas Emendadas, 26 Nov 1982 (fl.), $C$. Maury 317 (HEPH!). Goiás: entre Pirenópolis e Cocalzinho, Morro do Cabeludo, 16 Jan 1991 (fl.), J.A.N. Batista 156 (CEN!); cerca de $30 \mathrm{~km}$ de Caiapônia, sentido Piranhas-Goiás, represa da fazenda Samambaia, 18 Nov 1999 (fl.), C.P. Bove et al. 655 (CEN!, R!). Bahia: Barreiras, Riachão das Neves, $11^{\circ} 37^{\prime} 18^{\prime \prime} \mathrm{S}, 46^{\circ} 2^{\prime} 30^{\prime \prime} \mathrm{W}, 767 \mathrm{~m}$ a. s. 1 ., s.d., A. Cotrim et al. 271 (HUEFS!); A. Cotrim et al. 478 (HUEFS!).

Conservation status: Habenaria brachydactyla is a rare species, so far known only from five localities. Only two of the localities are inside established conservation areas: the Águas Emendadas Ecological Station in the Federal District and the Pirineus State Park in Goiás state. Its populations are apparently small, and only a few specimens were observed in bloom during three of the collections made by the authors. Herbarium collections of the species consist of only single (or at most a few) specimens. According to the IUCN Red List Categories and Criteria, and guidelines (IUCN 2012, 2016), this species can tentatively be classified as Endangered (EN), due to its small area of occupancy estimated in $20 \mathrm{~km}^{2}$ and small number of known populations containing few individuals [B2ab(iii); D].

Notes: In terms of its habit, Habenaria brachydactyla is similar to the other species, characterized as being slender, with linear leaves concentrated at the base of the stem, which includes $H$. irwiniana, $H$. minuta, $H$. pansarinii, and $H$. campylogyna. The distinctive features of $H$. brachydactyla are the very short lateral segments of its petals and lip, and the morphology of its rostelum, with a broad mid-lobe and parallel side-lobes, 0.4-0.5 mm long and turned forward. In terms of the morphology of its perianth, $H$. brachydactyla is similar to $H$. rotundiloba Pabst from the coastal plains of north-eastern Brazil, and to $H$. regnellii, from central, southeastern and southern Brazil and Paraguay, as they all have very reduced anterior petal segments and lateral lip segments. Habenaria rotundiloba, however, has leaves up to $15 \mathrm{~cm}$ long (vs 1.4-5.0 cm long in H. brachydactyla), appressed to the stem (vs spreading), larger flowers (dorsal sepal $5.5 \times 5.0 \mathrm{~mm}$ vs. $3.0-3.5 \times 2.5-2.8 \mathrm{~mm}$ in $H$. brachydactyla), the lateral segments of the lip rounded (vs subacute), and the spur clavate (vs linear). Habenaria regnelli also occurs in permanently wet habitats, its leaves are linear to oblonglanceolate and concentrated on the lower half of the stem, but not at the base of the stem, the perianth segments are fleshy, and the viscidia united. Habenaria brachydactyla is also similar in terms of its habit and flower morphology to $H$. pygmaea C.Schweinf. \& R.E.Schult., which is found in the sandy Amazonian savannas (white sand shrub vegetation) of Colombia and Venezuela (Schweinfurth and Schultes 1954; Carnevali and Ramírez 1985; Carnevali and Carnevali 1993). Habenaria pygmaea, however, has leaves lanceolate-elliptical, ovate, ovate-elliptical or elliptical (vs linear-lanceolate in H. brachydactyla), lateral lip lobes 3-5 $\mathrm{mm}$ long (vs 0.3-0.6 mm long), and a very distinct gynostemium, with the anthers spatulate, basally attenuate, connected at the base, but without any connective tissue (vs elliptical, not attenuate, and connected by connective tissue).

Habenaria brachydactyla is distinct from other Neotropical species of the genus in terms of its ecological preferences. As far as we could establish, it is the only Neotropical species of the genus that can grow with its vegetative portions completely submerged. Other aquatic or semiaquatic species, such as $H$. repens and $H$. melvillei Ridl., show the basal portions of their stems submerged, while the leaves are mostly or completely out of the water. Similar to those species, $H$. brachydactyla has a creeping, submerged, basal stem, and is apparently capable of vegetative reproduction, as the plants usually grow very near to each other and form clusters.

Habenaria irwiniana J.A.N.Bat. \& Bianch., sp. nov.TYPE: Brazil, Goiás, Chapada dos Veadeiros, Cavalcante, cerca de $28 \mathrm{~km}$ de Cavalcante, no alto da Chapada, em direção a região conhecida como São Domingos, 1 Jan 1999 (fl.), J.A.N. Batista 826 (holotype: BHCB!; isotypes: CEN!, MBM, RB, SP) (Figs. 4, 5a-d).

Etymology: Named after Howard S. Irwin, who first collected the species in 1966 at Chapada dos Veadeiros, in Central Brazil.

Habit similar to $H$. campylogyna, but distinct by having smaller leaves, $0.8-5.0 \times 0.15-0.2 \mathrm{~cm}$, smaller flowers, lateral sepals $3.0-4.0(-5.0) \times 1.5(-2.0)$, short anther canals, $0.3 \mathrm{~mm}$ long, short rostellum arms, $0.5-0.8 \mathrm{~mm}$ long, convergent towards the apices, stigmatophores closely parallel and closely spaced, and hemipollinaria united by the viscidia.

Terrestrial slender herb. Tuberoid root ellipsoid, $7-10 \times 3-5 \mathrm{~mm}$. Roots not examined. Stem erect, $10-22 \mathrm{~cm}$ long including the inflorescence, $0.5-1.0 \mathrm{~mm}$ wide. Leaves 4-5, spreading, largest at the base of the stem, linear, narrow, $0.8-5.0 \times 0.15-0.2 \mathrm{~cm}$; sheath-like leaves 
Fig. 4 Habenaria irwiniana: a habit; b leaf; c flower, front view; d dissected perianth; e pedicellate ovary, gynostemium, and spur, lateral view; $\mathbf{f}$ gynostemium, front view. All based on Batista 826 (BHCB). Drawn by Maria Helena Burian

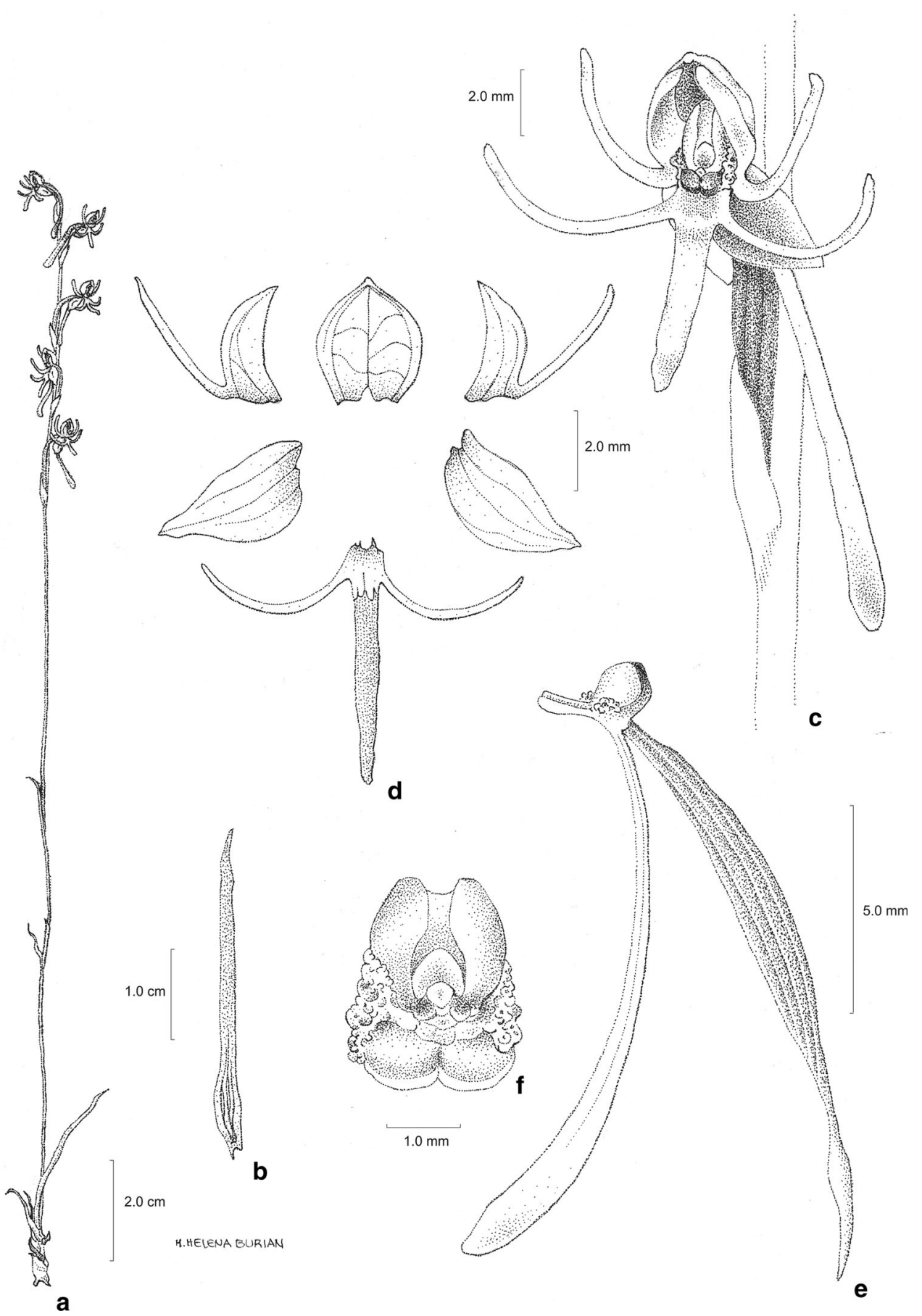

along the stem 1-2, spaced, $0.8-2.5 \mathrm{~cm}$ long. Inflorescence 2-8 cm long, few-flowered, lax; floral bracts elliptical to oblong, caudate to subcaudate, $3.0-7.0 \times 1.5-3.0 \mathrm{~mm}$, shorter than the pedicellate ovary. Flowers (1-)2-10, green; pedicellate ovary parallel to the rachis or spreading from it, $8-15 \mathrm{~mm}$ long; ovary slightly to strongly curved, 6-10 mm long; pedicel $2-5 \mathrm{~mm}$ long. Sepals green, discreetly mucronate, margins smooth; dorsal sepal concave, when flattened ovate, broadly elliptical or almost roundish, $2.5-3.5(-4.0) \times 2.0-3.0 \mathrm{~mm}$; lateral sepals obliquely lanceolate to obliquely elliptical, acute to subacute, reflexed, 3.0-4.0(-5.0) $\mathrm{mm} \times 1.5(-2.0) \quad \mathrm{mm}$. Petals bipartite, base whitish, towards the segments apex green or greenish yellow; posterior segment linear-falcate, $2.5-3.0(-4.0) \times 0.8-1.0 \mathrm{~mm}$, acute, adherent to the dorsal sepal or free, but not spreading; anterior segment erect, linear-filiform, inserted at the base of the posterior segment, (2-)3-5 mm long, usually longer than the posterior segment, rarely shorter. Lip tripartite, base whitish, towards the segments apex green or greenish yellow; undivided 

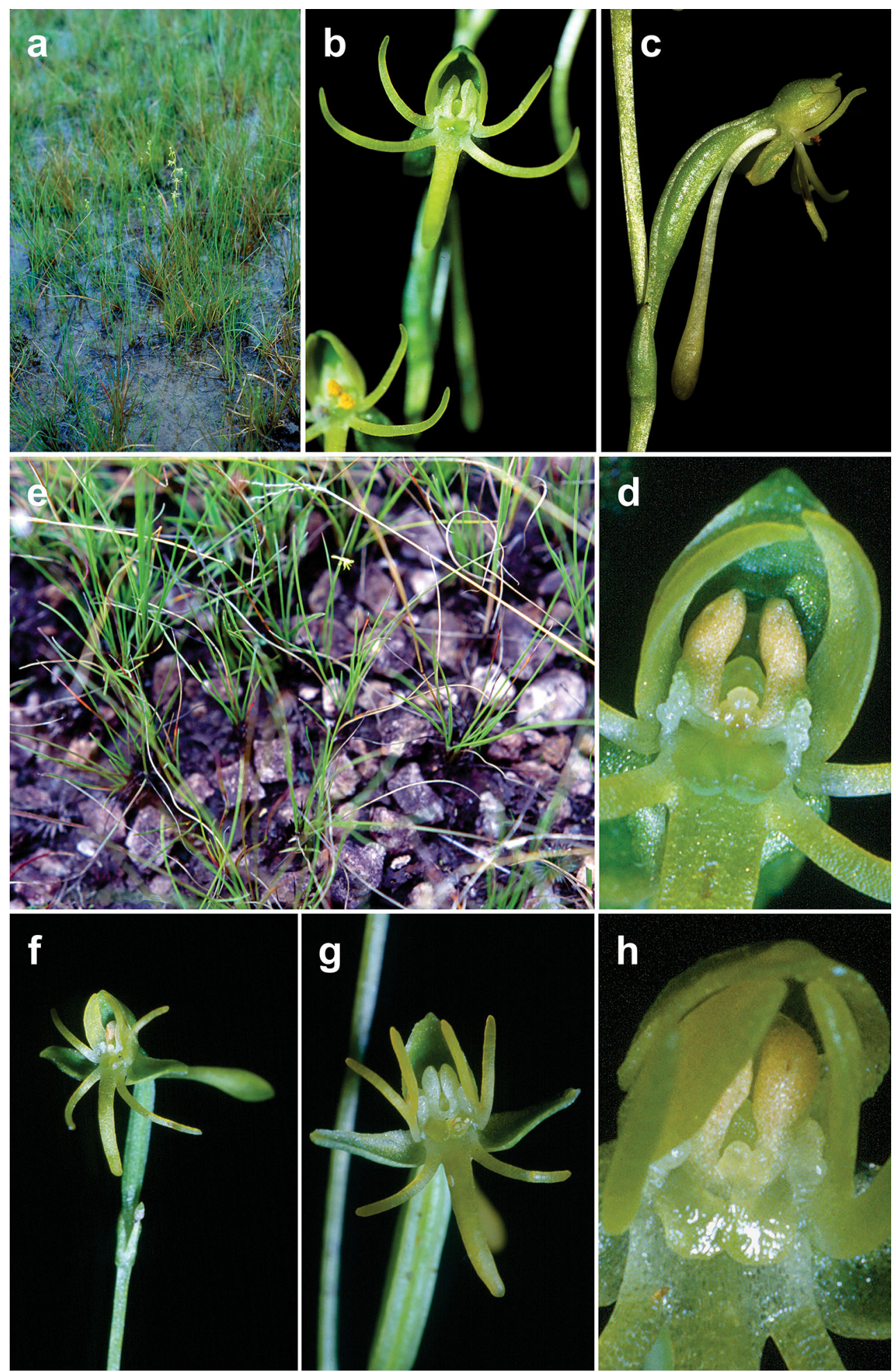

Fig. 5 Habenaria irwiniana: a habitat, permanently wet grassland (Chapada dos Veadeiros, Goiás state); b flower, front view; c flower, lateral view; d gynostemium, front view. Habenaria minuta: e habitat, dry campo limpo associated with campo rupestre (Chapada dos
Veadeiros, Goiás state, January 2001); f flower, lateral view; $\mathbf{g}$ flower, front view; h gynostemium, $3 / 4$ lateral view (b, d based on Batista 826 (BHCB); $\mathbf{c}$ based on Batista et al. 2956 (BHCB); $\mathbf{f}-\mathbf{h}$ based on Batista and Pansarin 1168(BHCB)). Photographs by J.A.N. Batista 
basal part short, $0.5-0.8 \mathrm{~mm}$ long; lateral segments somewhat perpendicular to the median segment, apex erect, linear-filiform, (2-)3-6 mm long, about the same size as the median segment; median segment linear, straight to slightly curved frontwards, 3.0-5.0($6.0) \times 0.8(-1.0) \mathrm{mm}$; spur direction variable, deflexed, slightly to markedly curved frontwards, or erect, free from the bracts, slightly clavate to clavate, about the same size as the pedicellate ovary, $8-15 \mathrm{~mm}$ long, base $0.5(-0.8) \mathrm{mm}$ wide, apex 1-1.3 mm wide, green. Gynostemium erect, $2 \mathrm{~mm}$ high; connective emarginate, green; lateral appendages (auricles) fleshy, verrucose, whitish, $0.5 \times 0.5 \mathrm{~mm}$, obtuse. Anther bilocular, loculi parallel, 1.0-1.5 mm high, canals short, $0.3 \mathrm{~mm}$ long; hemipollinaria joined by the viscidia, $1.5-1.8 \mathrm{~mm}$ long; viscidia $0.7 \times 0.4 \mathrm{~mm}$; caudicles $0.8 \mathrm{~mm}$ long; pollinia $1 \mathrm{~mm}$ long. Stigmatophores (stigma lobes) 2, closely parallel, touching each other throughout, $2 \mathrm{~mm}$ long, greenish, receptive surface convex, turned frontwards, $1.0-1.2 \mathrm{~mm}$ long, apex $0.5 \mathrm{~mm}$ wide, obtuse. Rostellum 1.2-1.5 mm long, light green; mid-lobe triangular, fleshy, obtuse, erect, completely placed between the anther loculi, $0.8 \mathrm{~mm}$ long, 0.8-1.0 mm high; sidelobes convergent towards the apices, $0.5-0.8 \mathrm{~mm}$ long.

Phenology: Flowering occurs during the peak of the rainy season, from late December to February (Table 3). A single record with flowers in July (Bosquetti 487 [ESA]) is dubious and most likely corresponds to a mistake in the data record. Similar to other Habenaria and terrestrial grassland orchids, flowering of the new species is enhanced by seasonal brush fires, and great concentrations of flowering plants were always found in burned sites during the dry season. Other orchid species such as Habenaria alpestris Cogn., H. caldensis, H. candolleana Cogn., H. edwallii Cogn., H. orchiocalcar Hoehne, $H$. guilleminii Rchb.f., H. heringeri Pabst, H. leprieurii Rchb.f., $H$. pabstii J.A.N. Bat. \& Bianch., Lyroglossa grisebachii (Cogn.) Schltr., Galeandra paraguayensis Cogn., Cleistes aphylla (Barb.Rodr.) Hoehne, and C. castaneoides Hoehne are sympatric, occurring in similar or adjacent habitats and flowering at about the same time.

Habitats: Habenaria irwiniana grows in seasonally to permanently wet grasslands, in dark sandy-clay soils, at altitudes from 1100 to $1600 \mathrm{~m}$ a.s.l. These fields usually accumulate surface water during the rainy season, but dry to greater or lesser extents during the dry season. These fields frequently occur associated with regularly spaced earthen mounds known as murundus.

Distribution area: Restricted to highlands in the core area of the Cerrado biome of central Brazil, and so far known only from the high-altitude grasslands of Chapada da Contagem in the Federal District, and Chapada dos Veadeiros, Serra dos Pirineus and Cristalina, in Goiás state.
Additional specimens examined: Brazil. Distrito Federal: Chapada da Contagem, DF-220, ao lado da Estação repetidora da Telebras, 28 Feb 1996 (fl.), J.A.N. Batista et al. 593 (CEN!); Goiás: Pirenópolis, 16 Jan 1991 (fl.), J.A.N. Batista 165 and 172 (CEN!); Pirenópolis, 17 Jan 1992 (fl.), J.A.N. Batista 249 (CEN!); Chapada dos Veadeiros, 20-25 km NO from Cavalcante, 21 Feb 1997 (fl.), J.A.N. Batista et al. 712 (CEN!); Chapada dos Veadeiros, 28 Jan 1993 (fl.), J.A.N. Batista and Bianchetti 397 (CEN!); Chapada dos Veadeiros, GO-118, about $37 \mathrm{~km} \mathrm{~N}$ from Alto Paraíso, km 203, 9 Jan 2001 (fl.), J.A.N. Batista and E.R. Pansarin 1150 (CEN!); Chapada dos Veadeiros, Municipality of Alto Paraíso, GO-118, towards Teresina de Goiás, about 19 km N from Alto Paraíso, 10 Jan 2001 (fl.), J.A.N. Batista and E.R. Pansarin 1159 (CEN!); Chapada dos Veadeiros, Municipality of Alto Paraíso, towards São Jorge, about $11 \mathrm{~km}$ after the crossroads with GO-118, 10 Jan 2001 (fl.), J.A.N. Batista and E.R. Pansarin 1166 (CEN!); Alto Paraíso, Chapada dos Veadeiros, ca. $27 \mathrm{~km} \mathrm{~N}$ de Alto Paraíso, $13^{\circ} 56^{\prime} 41^{\prime \prime} \mathrm{S}, 47^{\circ} 27^{\prime} 12^{\prime \prime} \mathrm{W}, 1490 \mathrm{~m}$ a. s. 1. 4 Feb 2010 (fl.), J.A.N. Batista et al. 2956 (BHCB!); Pico dos Pirineus, 15 Jan 1981 (fl.), L.B. Bianchetti 479 (HEPH!); Cocalzinho de Goiás, Parque Estadual da Serra dos Pirineus, 1230 m a. s. 1., 7 Jul 2006 (fl.), L.B. Bosquetti 487 (ESA!); 11 Feb 2007 (fl.), L.B. Bosquetti 582 (ESA!); Pirenópolis, Serra dos Pirineus, $21 \mathrm{~km}$ from Pirenópolis, 22 Feb 1995 (fl.), R. Cesar et al. 287 (UFG!, mixed with $H$. caldensis); Pirenópolis, Parque Estadual dos Pireneus, 27 Jan 2011 (fl.), J.E.Q. Faria 1029 (UB!); Chapada dos Veadeiros, $5 \mathrm{~km}$ E of Alto Paraíso, $1500 \mathrm{~m}$ a. s. 1., 25 Jan 1979 (fl.), Gates and Estabrook 64 (UB!); Chapada dos Veadeiros, $16 \mathrm{~km}$ by road $\mathrm{N}$ of Alto Paraíso, $1600 \mathrm{~m}$ a. s. 1., 5 Feb 1979 (fl.), Gates and Estabrook 156 (RB!, SP!, UB!; mixed with H. leprieurii); Chapada dos Veadeiros, $5 \mathrm{~km}$ E of Alto Paraíso, $1550 \mathrm{~m}$ a. s. 1., 16 Feb 1979 (fl.), Gates and Estabrook 216 (HB!, RB!, SP!, UB!) (mixed with H. minuta); Chapada dos Veadeiros, 21 Dec 1968 (fl.), R.M. Harley et al. 11391 (K!); BR-040, 5-10 km W from Cristalina, $1250 \mathrm{~m}$ a. s. 1., Serra dos Cristais, 24 Jan 1988 (fl.), G. Hatschbach and J. Cordeiro 51833 (G!, HBG!, MBM!); Pirenópolis, Serra dos Pirineus, rodovia Pirenópolis-Cocalzinho de Goiás, 13 Feb 2000 (fl.), G. Hatschbach et al. 70138 (MBM!); Cristalina, $1200 \mathrm{~m}$ a. s. 1., 2 Feb 1967 (fl.), Heringer 11344 (HB!, UB!); Chapada dos Veadeiros, $15 \mathrm{~km} \mathrm{~W}$ of Veadeiros, $1000 \mathrm{~m}$ a. s. 1., 9 Feb 1966 (fl.), H.S. Irwin et al. 12383 (HB!, IAN!, NY!, S!, UB!); $20 \mathrm{~km}$ E of Pirenópolis, Serra dos Pirineus, $1000 \mathrm{~m}$ a. s. 1., 14 Jan 1972 (fl.), H.S. Irwin et al. 34075 (UB!); $18 \mathrm{~km}$ E of Pirenópolis, Serra dos Pirineus, $1000 \mathrm{~m}$ a. s. 1., 15 Jan 1972 (fl.), H.S. Irwin et al. 34223 (HB!, NY!, UB!); $21 \mathrm{~km}$ E of Pirenópolis, Serra dos Pirineus, $1000 \mathrm{~m}$ a. s. 1., 19 Jan 1972 (fl.), H.S. Irwin et al. 34604 (UB!); estrada Pirenópolis-Pirineus, 10 Jan 1981 (fl.), N.L. Menezes in 
CFCR 622 (SP!, SPF!); Cavalcante, área a noroeste de Cavalcante, cerca de 20-25 km na margem da estrada para a região conhecida localmente como São Domingos, 21 Feb 1997 (fl.), R.S. Oliveira et al. s.n. (UB!); Terezina de Goiás, rodovia GO 118, km 197.5, sentido Alto Paraíso de Goiás-Terezina de Goiás, $13^{\circ} 55^{\prime} \mathrm{S}, 4^{\circ} 26^{\prime} \mathrm{W}, 2$ Jan 2001 (fl.), E.R. Pansarin and L.Mickeliunas 884 (UEC!); Cristalina, $16^{\circ} 46^{\prime} \mathrm{S}-47^{\circ} 37^{\prime} \mathrm{W}, 1,050 \mathrm{~m}$ a. s. $1 ., 5 \mathrm{~km}$ da cidade na estrada para Paracatu, 4 Feb 1987 (fl.), J.R. Pirani et al. 1530 (SPF!, mixed with H. alpestris); Cristalina, BR-040, $3 \mathrm{~km}$ ao norte da cidade, $16^{\circ} 43^{\prime} \mathrm{S}, 47^{\circ} 37^{\prime} \mathrm{W}, 860 \mathrm{~m}$ a. s. 1 ., 7 Feb 2002 (fl.), A.O. Simões et al. 1193 (UEC!); Alto Paraíso, on the road towards Campos Belos, GO-118, km $174,13^{\circ} 46^{\prime} \mathrm{S}, 47^{\circ} 30^{\prime} \mathrm{W}, 680-700 \mathrm{~m}$ a. s. 1., 22 Feb 1995 (fl.), S. Splett 762 (CEN!, UB!); Alto Paraíso de Goiás, Alto Paraíso/Colinas do Sul, cerca de $3 \mathrm{~km}$ da GO-118, $14^{\circ} 09^{\prime} 22^{\prime \prime} \mathrm{S}, 47^{\circ} 32^{\prime} 43^{\prime \prime} \mathrm{W}, 1,200 \mathrm{~m}$ a. s. 1., 27 Jan 1997 (fl.), B.M.T. Walter et al. 3634 (CEN!).

Conservation status: Several large populations of $H$. irwiniana are known from Chapada dos Veadeiros, many growing inside the Chapada dos Veadeiros National Park. Other populations, generally smaller, are found in the Serra dos Pirineus State Park and Cristalina, in Goiás state. The species is rare and known only by a single population in the Federal District. According to the IUCN Red List Categories and Criteria, and guidelines (IUCN 2012, 2016), the species can be tentatively classified as Endangered (EN), due to its small area of occupancy estimated in $72 \mathrm{~km}^{2}$ and known to exist at no more than five locations [B2ab(iii)].

Illustrations: Pabst and Dungs (1975, p. 255, Figure 151, as H. humilis Cogn.), Bianchetti et al. (2006, p. 162, Figure 19, colour photograph, as $H$. aff. humilis).

Notes: As far as we could determine, Habenaria irwiniana was first collected by Howard S. Irwin at Chapada dos Veadeiros, Goiás state, in 1966. This is one of the several new species of Habenaria that were first collected from the 1960s onwards when systematic botanical explorations of the Brazilian central plateau were initiated by Howard S. Irwin and colleagues. Guido F.J. Pabst was probably the first orchid taxonomist to examine the material of this species, but misidentified it as $H$. humilis Cogn. $(=H$. campylogyna). In his personal notes, in the Herbarium Bradeanum, Pabst also identified the species as $H$. humilis f. minor, but never published this name. In a published checklist of the Orchidaceae of the Federal District (Batista and Bianchetti 2003), and in an account of the Orchidaceae of APA de Cafuringa (Bianchetti et al. 2006), H. irwiniana was recorded as $H$. aff. humilis. Habenaria irwiniana, in fact, is similar to H. campylogyna in terms of their habits, but the two species differ by the characters outlined in Table 4. Particularly distinctive characters are the lengths and widths of the leaves $(8-50 \times 1.5-2.0 \mathrm{~mm}$ in $H$. irwiniana vs $35-105 \times 2-4 \mathrm{~mm}$ in $H$. campylogyna), lengths and directions of the rostelum arms $(0.5-0.8 \mathrm{~mm}$ long and convergent in $H$. irwiniana vs $2.5 \mathrm{~mm}$ long and slightly divergent towards the apices in $H$. campylogyna), and the positions of their stigmatophores (closely parallel and in contact with each other in $H$. irwiniana vs separate in H. campylogyna).

In terms of flower morphology, particularly of the gynostemium, $H$. irwiniana is similar to other species such as $H$. alpestris, H. secundiflora Barb.Rodr., H. balansae, and $H$. melanopoda, being characterized by a slender habit, linear leaves, small flowers, stigmatophores closely parallel, and hemipollinaria joined by the viscidia. It is distinct from all these taxa, however, by having its leaves concentrated at the base of the stem, versus spaced along the stem with the largest leaves usually concentrated in the middle of the stem. In terms of general flower morphology, $H$. irwiniana is also similar to $H$. ayangannensis, although the latter species has linear-filiform leaves spaced along the stem, overlapping flowers, and separate hemipollinaria.

Habenaria minuta J.A.N.Bat. \& Bianch., sp. nov.TYPE: Brazil, Goiás, Alto Paraíso, Chapada dos Veadeiros, cerca de $11 \mathrm{~km}$ após e a oeste da difurcação com a GO-118, em direção a São Jorge, 10 Jan 2001 (fl.), J.A.N. Batista and E.R. Pansarin 1168 (holotype: BHCB!; isotypes: CEN!, MBM, RB, SP) (Figs. 5e-h, 6).

Etymology: From the Latin minutus (very small), referring to the very small sizes of both the plants and flowers of this new species, one of the smallest among New World Habenaria.

Habit similar to $H$. irwiniana, but distinct by growing in campo rupestre (rocky field) vegetation, smaller plants (6-14 cm tall), shorter spurs (5-7 mm long), straight, reflexed, perpendicular to the ovary, smaller rostellum $(0.7-0.8 \times 0.5 \mathrm{~mm})$, shorter stigmatophores $(0.8 \mathrm{~mm}$ long), and smaller pollinaria (1.0-1.2 mm long).

Terrestrial slender herb. Roots few, short, 0.7-1.0 mm wide, glabrous, whitish. Tuberoid root ellipsoid, 4-5 × 2-3 mm. Stem erect, 6-14 cm long including the inflorescence, 0.3-0.4 mm wide. Leaves 4-5, spreading, largest at the base of the stem, linear, narrow, $0.6-0.9 \times 0.1-0.15 \mathrm{~cm}$; sheath-like leaves along the stem (1-)2(-3), 0.25-0.7 cm long. Inflorescence 1-4 cm long, few-flowered, lax; floral bracts ovate, apiculate, 2.0-3.0 $\times 1.2-2.0 \mathrm{~mm}$, shorter than the pedicellate ovary. Flowers 1-2(-3), green; pedicellate ovary parallel to the rachis, $7.0-9.0 \mathrm{~mm}$ long, ovary slightly curved, 5.0-6.0 mm long, pedicel 2.4-3.7 mm long. Sepals green, discreetly mucronate, margins smooth; dorsal sepal concave, when flattened ovate, $2.0-2.8 \times 1.5-2.3 \mathrm{~mm}$; lateral 
Table 4 Diagnostic characters for the Brazilian Habenaria, being slender, delicate plants, with linear leaves concentrated at the base of the stem

\begin{tabular}{|c|c|c|c|c|c|c|}
\hline & H. brachydactyla & H. irwiniana & H. minuta & H. campylogyna & H. pansarinii & $\begin{array}{l}\text { H. pansarinii var. } \\
\text { minuscula }\end{array}$ \\
\hline $\begin{array}{l}\text { Stem length, including the } \\
\text { inflorescence }(\mathrm{cm})\end{array}$ & $14-28$ & $10-22$ & $6-14$ & $7-18(-24)$ & $7-27$ & $7-28$ \\
\hline Leaves length $\times$ width $(\mathrm{mm})$ & $14-50 \times 2-5$ & $8-50 \times 1.5-2.0$ & $6-9 \times 1.0-1.5$ & $35-105 \times 2-4$ & $15-55 \times 2-5$ & $8-26 \times 1-4$ \\
\hline Pedicellate ovary length $(\mathrm{mm})$ & $11-15$ & $8-15$ & $7-9$ & $13-19$ & $5.4-9.4$ & $6.7-8.1$ \\
\hline Lateral sepals length (mm) & $3.5-4.0$ & $3.0-4.0(-5.0)$ & $2.5-3.0$ & $5.5-7.0$ & $2.9-3.7$ & $2.2-3.1$ \\
\hline Posterior petals length (mm) & $3.0-3.3$ & $2.5-3.0(-4.0)$ & $2.0-2.8$ & $4.0-6.0$ & $2.5-3.5$ & $2.1-2.7$ \\
\hline Anterior petal length (mm) & $(0.0-) 0.3-0.5$ & $(2-) 3-5$ & $2.5-3.0$ & $3.5-4.0(-6.0)$ & $3.6-5.4$ & $1.1-2.5$ \\
\hline $\begin{array}{l}\text { Lip undivided base length } \\
(\mathrm{mm})\end{array}$ & 0.5 & $0.5-0.8$ & 0.5 & $1.5-3.0$ & $0.7-1.1$ & $0.6-0.7$ \\
\hline $\begin{array}{l}\text { Lip lateral segments length } \\
(\mathrm{mm})\end{array}$ & $(0.0-) 0.3-0.6$ & $(2-) 3-6$ & $2.2-2.8$ & $6-8$ & $3.5-5.4$ & $1.5-2.2$ \\
\hline $\begin{array}{l}\text { Lip median segment length } \\
(\mathrm{mm})\end{array}$ & $2.0-3.0$ & $3.0-5.0(-6.0)$ & $2.3-2.8$ & $4.0-5.0(-6.0)$ & $3.2-4.3$ & $1.7-2.5$ \\
\hline Spur length (mm) & $9-11$ & $8-15$ & $5-7$ & $10-13$ & $2.3-3.8$ & $1.2-1.4$ \\
\hline Spur direction & $\begin{array}{l}\text { Deflexed to } \\
\text { curved forward }\end{array}$ & $\begin{array}{l}\text { Deflexed to } \\
\text { curved forward }\end{array}$ & Reflexed & $\begin{array}{l}\text { Strongly curved } \\
\text { forward }\end{array}$ & Deflexed & Deflexed \\
\hline Anther canal length (mm) & $0.5-0.7$ & 0.3 & 0.15 & $1.8-2.5$ & 0 & 0 \\
\hline Hemipollinaria & Separate & United & United & Separate & United & United \\
\hline Stigmatophore length (mm) & 1.3 & 2.0 & 0.8 & $2.3-2.5$ & $1.0-1.4$ & - \\
\hline Stigmatophores & Separate & Together & Together & Separate & Together & Together \\
\hline $\begin{array}{l}\text { Rostellum side-lobes length } \\
\quad(\mathrm{mm})\end{array}$ & $0.4-0.5$ & $0.5-0.8$ & 0.35 & ca. 2.5 & 0.4 & - \\
\hline $\begin{array}{l}\text { Rostellum side-lobes } \\
\text { direction }\end{array}$ & Parallel & Convergent & Convergent & Divergent & Convergent & Convergent \\
\hline Distribution & $\mathrm{DF}, \mathrm{GO}, \mathrm{BA}$ & $\mathrm{DF}, \mathrm{GO}$ & GO & MG & MG & MG \\
\hline
\end{tabular}

Abbreviations for Brazilian states: $B A$ Bahia; $G O$ Goiás; $M G$ Minas Gerais. $D F$ Federal District. An en-dash denotes not measured

sepals obliquely ovate, obtuse or subacute, patent, 2.5-3.0 × 1.0-1.3 mm. Petals bipartite, base whitish, towards the segments apex green or greenish yellow; posterior segment ovate, falcate, $2.0-2.8 \times 0.8-1.0 \mathrm{~mm}$, acute, adherent to the dorsal sepal; anterior segment erect, linear-filiform, inserted at the base of the posterior segment, 2.5-3.0 mm long, about the same size as posterior segment. Lip tripartite, base whitish, towards the segments apex green or greenish yellow; undivided basal part short, $0.5 \mathrm{~mm}$ long; lateral segments deflexed, linear-filiform, 2.2-2.8 $\mathrm{mm}$ long, about the same size as the median segment; median segment linear, straight, 2.3-2.8 $\times 0.8 \mathrm{~mm}$, spur reflexed, perpendicular to the ovary, free from the bracts, clavate, shorter than the pedicellate ovary, 5-7 $\mathrm{mm}$ long, base $0.5 \mathrm{~mm}$ wide, apex $0.7-1.3 \mathrm{~mm}$ wide, green. Gynostemium erect, $1.5-1.8 \mathrm{~mm}$ high; connective emarginate, narrow, green; lateral appendages (auricles) fleshy, verrucose, whitish, $0.6 \times 0.4 \mathrm{~mm}$. Anther bilocular, loculi parallel, $0.8-1.0 \mathrm{~mm}$ high, canals short, $0.15 \mathrm{~mm}$ long; hemipollinaria joined by the viscidia, 1.0-1.2 $\mathrm{mm}$ long, viscidia ellipsoidal, large relative to size of the pollinia,
$0.25-0.3 \times 0.1-0.15 \mathrm{~mm}$, caudicles $0.2 \mathrm{~mm}$ long, pollinia $0.7 \mathrm{~mm}$ long. Stigmatophores (stigma lobes) 2, closely parallel, touching each other throughout, $0.8 \mathrm{~mm}$ long, green, receptive surface flat, turned frontwards, apex $0.6 \mathrm{~mm}$ wide, obtuse. Rostellum $0.7-0.8 \mathrm{~mm}$ long, green, mid-lobe triangular, fleshy, obtuse, erect, completely placed between the anther loculi, $0.5 \mathrm{~mm}$ high, side-lobes convergent towards the apices, $0.35 \mathrm{~mm}$ long.

Phenology: Flowering occurs during the peak of the rainy season, from late December to February (Table 3). Similar to other Habenaria and terrestrial grassland orchids, the flowering of the new species is apparently enhanced by seasonal brush fires. The only population of the species found by the authors was located in an area that had burned during the dry season.

Habitats: Habenaria minuta grows in seasonally humid campos rupestres (rocky field) sites, with dark, shallow, rocky, sandy-clay soils, at 1100-1600 $\mathrm{m}$ a.s.1. The soil can be humid during some periods in the rainy season, but dries out completely during the dry season. Cleistes pusilla 
Fig. 6 Habenaria minuta: a habit; b leaf; c flower, $3 / 4$ lateral view; d dissected perianth; e bract; $\mathbf{f}$ pedicellate ovary, gynostemium, and spur, lateral view. All based on Batista and Pansarin 1168 (BHCB). Drawn by Maria Helena Burian

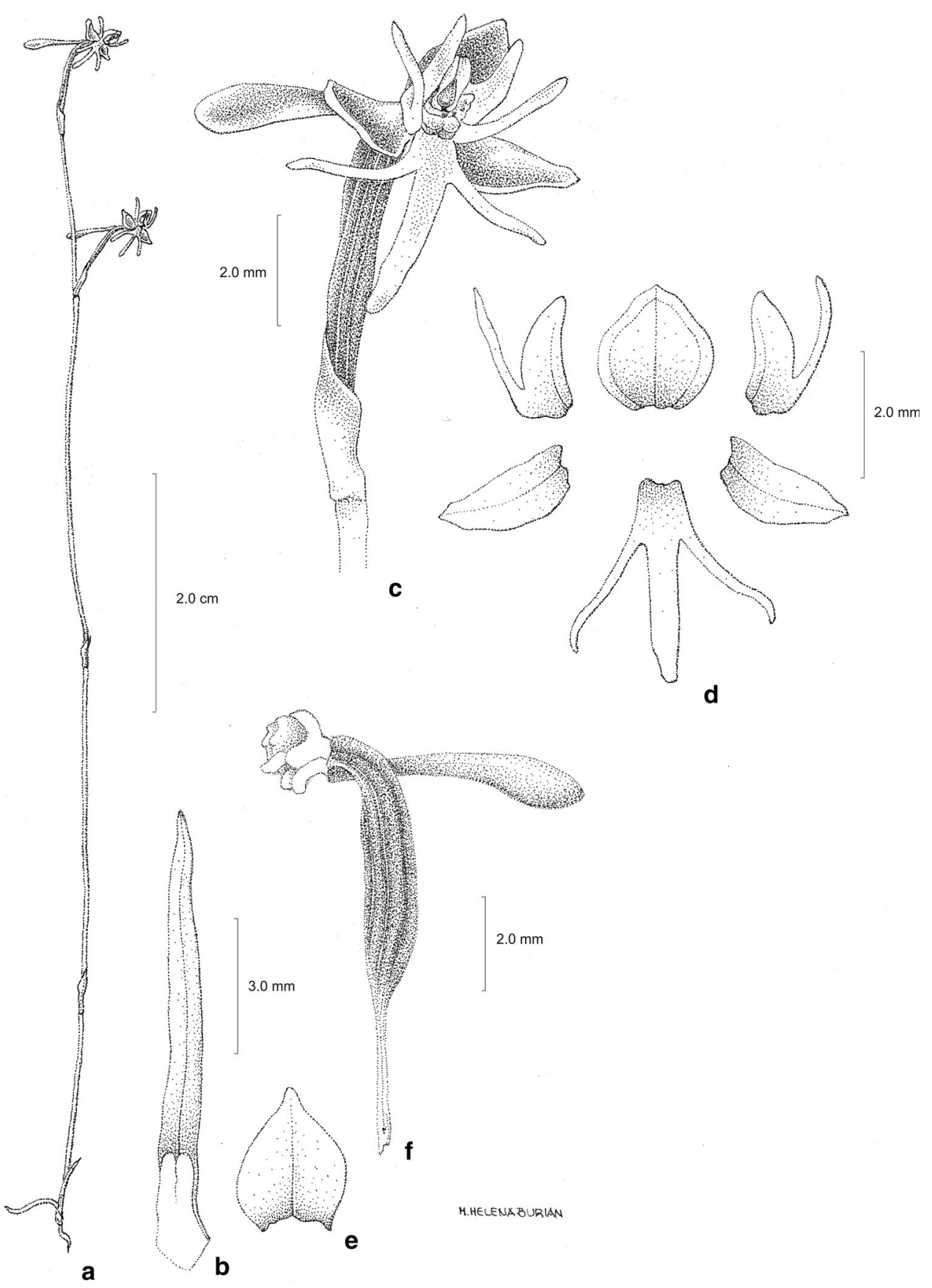

Pansarin is sympatric, occurring in exactly the same habitat and flowering at the same time. Other species, such as $H$. irwiniana and $H$. orchiocalcar, occur in adjacent habitats and also flower at the same time.

Distribution area: Restricted to Chapada dos Veadeiros, in Goiás state in central Brazil.

Additional specimens examined: Brazil. Goiás: Alto Paraíso de Goiás, $5 \mathrm{~km}$ E of Alto Paraíso, Chapada dos Veadeiros, $14^{\circ} \mathrm{S}, 47^{\circ} \mathrm{W}, 1550 \mathrm{~m}$ a. s. $1 ., 16$ Feb 1979 (fl.),
Gates and Estabrook 216 (HB!, RB!, SP!, UB!) (mixed with $H$. irwiniana); Terezina de Goiás, rodovia GO 118, km 189, sentido Alto Paraíso de Goiás-Terezina de Goiás, $13^{\circ} 57^{\prime} \mathrm{S}, 47^{\circ} 28^{\prime} \mathrm{W}, 31$ Dec 2001 (fl.), E.R. Pansarin and L. Mickeliunas 874 (UEC!).

Conservation status: Habenaria minuta is a rare species, currently known from only three collections from Chapada dos Veadeiros, in northern Goiás state. The plants are difficult to find in the field as they are very small and slender, and grow among grasses. In the type locality, 
about 25 plants in flower were observed. In a 3-day expedition to Chapada dos Veadeiros searching for Habenaria species, only this single population of $H$. minuta was found. According to the IUCN Red List Categories and Criteria, and guidelines (IUCN 2012, 2016), the species can tentatively be classified as Critically Endangered (CR), due to its limited geographic range (extent of occurrence estimated in $107 \mathrm{~km}^{2}$ ), small area of occupancy estimated in $12 \mathrm{~km}^{2}$, and three known populations $[\mathrm{B} 1 \mathrm{ab}(\mathrm{iii})+2 \mathrm{a}-$ b(iii); $\mathrm{C} 2 \mathrm{a}(\mathrm{i})]$.

Notes: Material from $H$. minuta suitable for molecular analysis was not available. Based on morphological similarities the species most closely related to $H$. minuta is $H$. irwiniana, which occurs in the same locality. However, $H$. minuta is readily distinguished by being smaller, with smaller flowers, and a shorter spur that is straight, reflexed, and usually perpendicular to the ovary. Additionally, $H$. minuta grows among rocks, in sandy soil, at drier sites in campo rupestre (rocky field) vegetation, while $H$. irwiniana is typically found in meadows that are usually humid throughout the year.

Habenaria minuta is probably the smallest species among New World Habenaria in terms of its vegetative and reproductive structures. Habenaria brachyphyton Schltr., from the southern coast of Brazil, shows plants as short and flowers as small as those of $H$. minuta, but its leaves are more developed and its inflorescence presents many more flowers. Plants of $H$. guilleminii and $H$. pygmaea, among some others, can also be very small, but the leaves of those species are more developed and their flowers usually slightly larger. Other species, such as $H$. subfiliformis Cogn., $H$. paulensis Porsch, $H$. imbricata Lindl., and $H$. parviflora can also produce very small flowers, but their leaves are usually more developed and/or the plants taller.

Habenaria pansarinii J.A.N.Bat. \& Bianch., sp. nov.TYPE: Brazil, Minas Gerais, Presidente Kubitschek, BR259, $\mathrm{km} \mathrm{442,} \mathrm{2,8} \mathrm{km} \mathrm{do} \mathrm{entroncamento} \mathrm{para} \mathrm{Presidente}$ Kubitschek no sentido para datas, $18^{\circ} 34^{\prime} \mathrm{S}, 43^{\circ} 35^{\prime} \mathrm{W}$, 1175 m a. s. 1., 14 Feb 2007 (fl.), J.A.N. Batista, R.C. Mota, M.W.F. Faria and H.R. El Bizri 1926 (holotype: BHCB 119604!; isotypes: CEN, MBM, RB, SP) (Figs. 7, 8c-e and 9c, d).

Etymology: Named after Emerson Ricardo Pansarin, a colleague and authority in the systematics of Vanilloideae, who collected the specimens that first drew our attention to this species.

Habit and general floral morphology similar to $H$. irwiniana, but distinct by having a shorter pedicellate ovary ((4.4-)5.4-9.4 mm long), and a short and saccate spur
(2.3-3.8 mm long) that is shorter than the pedicellate ovary; distribution restricted to the Espinhaço Range of Minas Gerais state.

Terrestrial slender herb. Tuberoid root not examined. Roots not examined. Stem erect, 7-27 cm long, including the inflorescence, $0.4-0.8 \mathrm{~mm}$ wide. Leaves $2-5$, concentrated at the stem base, spreading, linear-lanceolate, $1.5-5.5 \times 0.2-0.5 \mathrm{~cm}$, along the stem with $1-2(-3)$ sheathlike leaves. Inflorescence (0.7-)3.0-9.0(-14.0) cm long, lax, spiral; floral bracts ovate, apiculate, 2.1-6.4 $\times$ 1.5-2.1 mm, shorter than the pedicellate ovary. Flowers (1-)3-13(-21), greenish; pedicellate ovary parallel to the rachis or spreading, (4.4-)5.4-9.4 mm long; ovary straight, (3.3-)4.5-7.5 mm long; pedicel 1.0-2.9 mm long. Sepals green, margins smooth; dorsal sepal concave, when flattened ovate, $2.6-3.4 \times 2.2-2.8 \mathrm{~mm}$; lateral sepals obliquely lanceolate, spreading, $2.9-3.7 \times 1.2-1.5 \mathrm{~mm}$. Petals bipartite, base whitish, segments green or greenish yellow; posterior segment lanceolate, 2.5-3.5 × 0.8-1.0 mm, acute, adherent to the dorsal sepal; anterior segment erect, filiform, inserted at the base of the posterior segment, 3.6-5.4 mm long, 1.3-1.6 times as long as the posterior segment. Lip tripartite; undivided basal part short, $0.7-1.1 \times 0.8-1.4 \mathrm{~mm}$, whitish; segments green or greenish yellow; lateral segments pendent, towards the apices reflexed, linear, 3.5-5.4 mm long, (0.9-)1.0-1.3 times as long as the median segment; median segment linear, $3.2-4.3 \times 0.6-0.7 \mathrm{~mm}$; spur free from the bracts, saccate, $2.3-3.8 \times 1.0-1.3 \mathrm{~mm}, 0.4-0.6$ times as long as the pedicellate ovary, greenish. Gynostemium erect, $0.9-1.1 \mathrm{~mm}$ high; connective emarginate, light green; lateral appendages (auricles) fleshy, verrucose, light green, $0.7 \times 0.3-0.4 \mathrm{~mm}$, truncate. Anther bilocular, loculi parallel, $0.7-0.8 \mathrm{~mm}$ high, canals absent; hemipollinaria joined by the viscidia; viscidia ellipsoidal, $0.2 \times 0.1 \mathrm{~mm}$; caudicles $0.15-0.2 \mathrm{~mm}$ long. Stigmatophores (stigma lobes) 2, closely parallel, together, 1.0-1.4 mm long, green, receptive surface, turned frontwards, $0.6-0.7 \mathrm{~mm}$ long, apex $0.5 \mathrm{~mm}$ wide, obtuse. Rostellum $0.7 \mathrm{~mm}$ long, light green; mid-lobe triangular, fleshy, obtuse, erect, completely placed between the anther loculi, $0.3 \mathrm{~mm}$ long, $0.3 \mathrm{~mm}$ high; side-lobes convergent towards the apices, $0.4 \mathrm{~mm}$ long.

Phenology: Flowering occurs from the middle to the early end of the rainy season, during February and March (Table 3). Flowering is greatly enhanced by seasonal brush fires, and high densities of flowering plants were consistently found in sites that had burned during the dry season. Orchid species such as Habenaria pubidactyla subsp. pubidactyla, $H$. secundiflora, $H$. mystacina Lindl., $H$. guilleminii, $H$. leprieurii, and Cleistes castaneoides are sympatric, occur in similar or adjacent habitats, and flower at about the same time. 
Fig. 7 Habenaria pansarinii: a habit; b leaf; c flowers, front and lateral view; $\mathbf{d}$ dissected perianth; e bract, pedicellate ovary, gynostemium, and spur, lateral view; f gynostemium, front view; $\mathbf{g}$ gynostemium, lateral view. Drawn by Maria Helena Burian

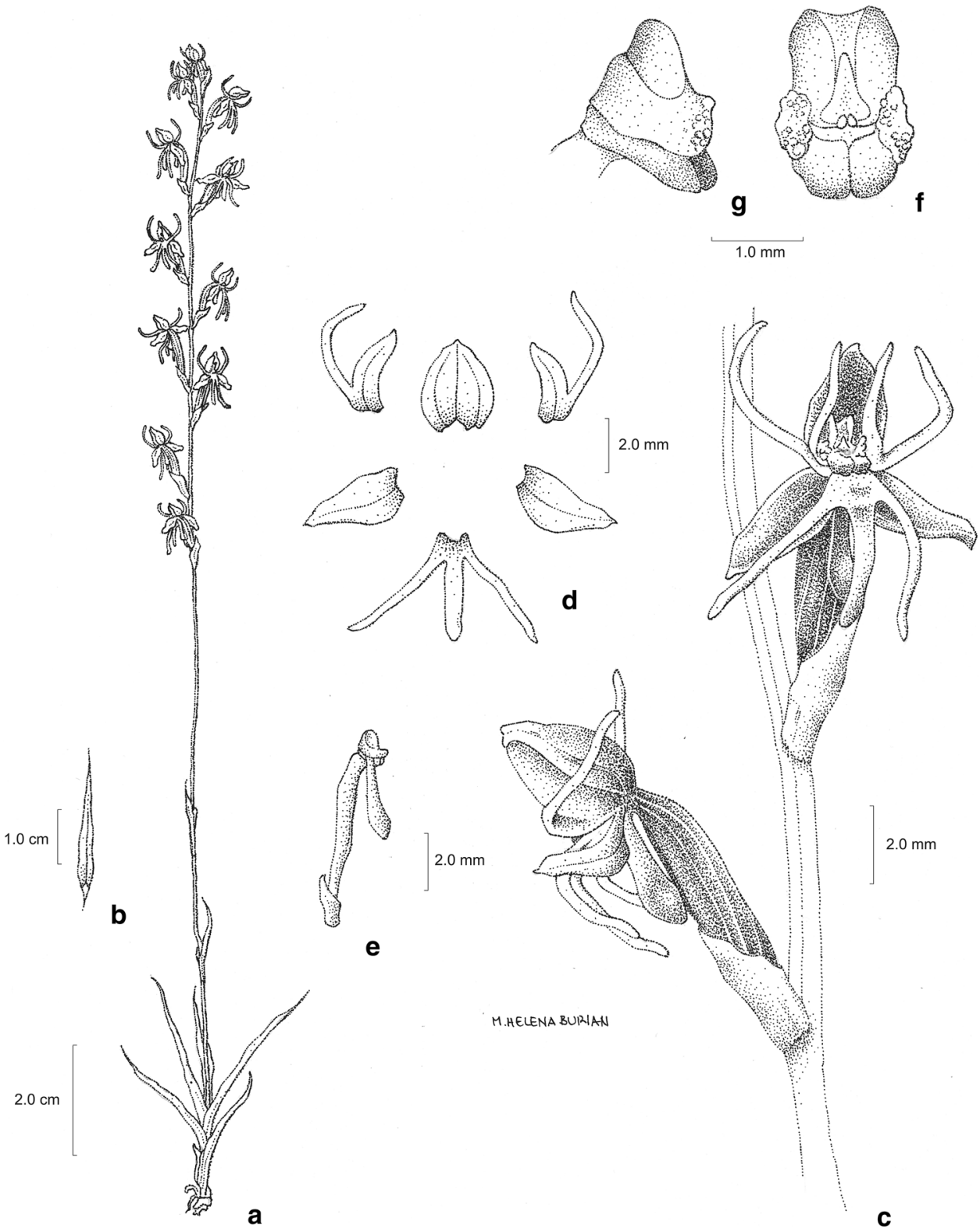

Habitat: In seasonally humid herbaceous vegetation associated with quartzite outcrops, frequently growing on a thin layer of earth and humus accumulated over the outcrop, locally called 'lageados', with dark, shallow, sandy-clay soils, at 1000-1300 m a.s.l. These environments usually accumulate surface water during the rainy season, but dry to a greater or lesser extent during the dry season. Several species of Drosera (Droseraceae), Xyris (Xyridaceae), Velloziaceae, and Eriocaulaceae grow in the same environment.

Distribution area: Restricted to the central part of the Espinhaço Range in Minas Gerais state, from the municipalities of Presidente Kubitschek and Datas to the Diamantina plateau and São Gonçalo do Rio Preto.
Additional specimens examined: Brazil. Minas Gerais: Serro, Milho Verde, Lageado, $18^{\circ} 28^{\prime} \mathrm{S}, 4^{\circ} 28^{\prime} \mathrm{W}, 1097 \mathrm{~m}$ a. s. 1., 16 Feb 2007 (fl.), J.A.N. Batista et al. 1957 (BHCB!); São Gonçalo do Rio Preto, Parque Estadual do Rio Preto, trilha para a Chapada, $18^{\circ} 10^{\prime} \mathrm{S}, 43^{\circ} 19^{\prime} \mathrm{W}$, 1131 m a. s. 1., 20 Mar 2007 (fl.), J.A.N. Batista et al. 2024 (BHCB!); Diamantina, estrada entre Macacos e a sede do Parque Nacional das Sempre Vivas, nos Campos de São Domingos, $17^{\circ} 57^{\prime} \mathrm{S}, 43^{\circ} 47^{\prime} \mathrm{W}, 1224$ m a. s. 1., 8 Mar 2009 (fl.), J.A.N. Batista et al. 2868 (BHCB!); Datas, BR-259, km 433, 18 Mar 1987 (fl.), G. Hatschbach 51133 (MBM!); Serro, Milho Verde, Serra do Ouro, 1 Feb 2003 (fl.), R.C. Mota 1730 (BHCB!, CEN!); Presidente Kubischeck, rodovia sentido Presidente Kubischeck-Serro, a cerca de $7 \mathrm{~km}$ da cidade, 12 Feb 2001 (fl.), E.R. Pansarin and A.O. 

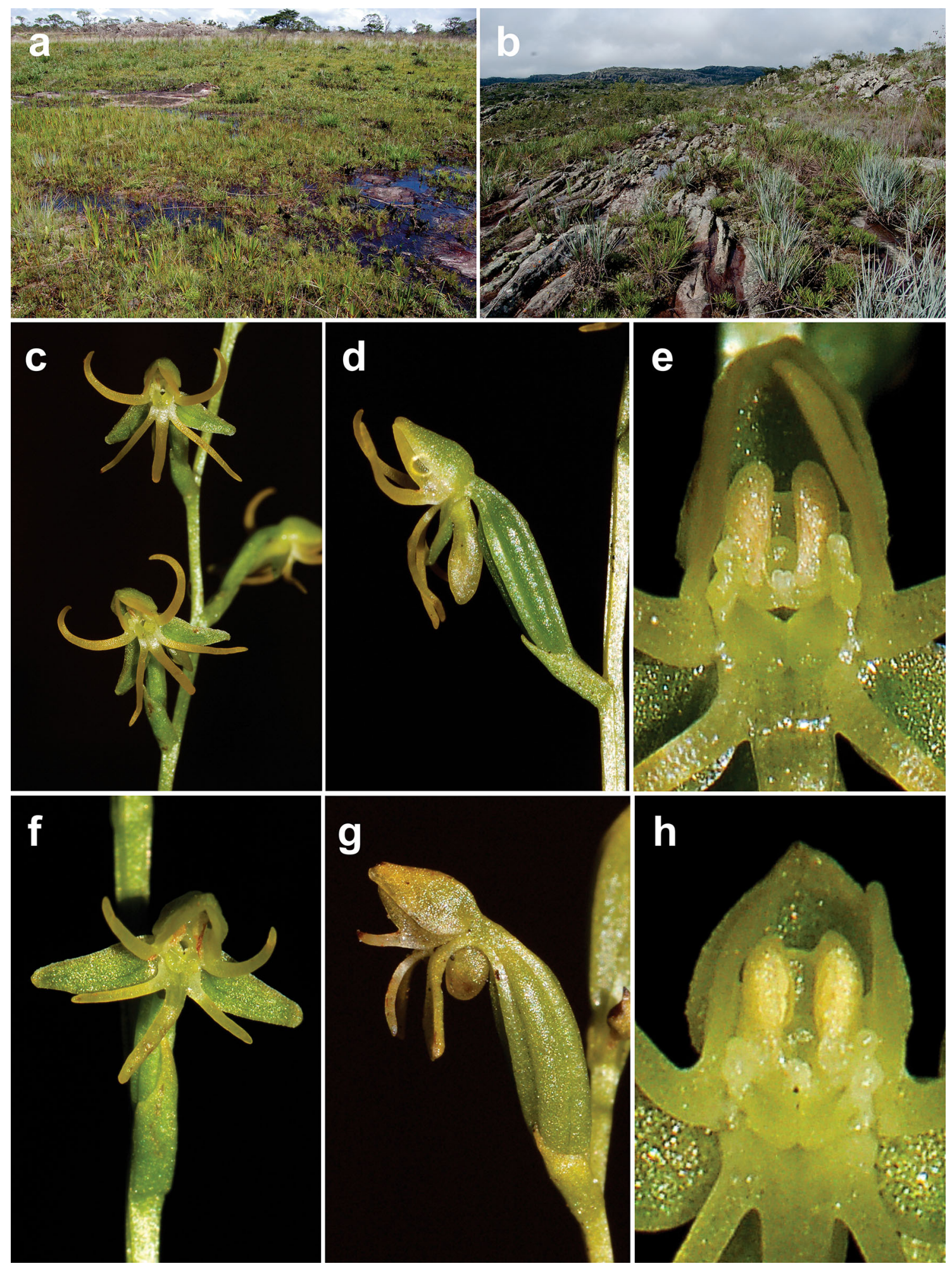

Fig. 8 Habenaria pansarinii: a habit, seasonally humid herbaceous vegetation associated with quartzite outcrops (Lageado, Milho Verde, Serro, Minas Gerais state; February/2007); b habitat, campo rupestre on quartzite outcrops (Macacos, Diamantina, Minas Gerais state; March/2009); c flowers, 3/4 lateral view; d flower, lateral view;

e gynostemium, front view. Habenaria pansarinii var. minuscula; f flower, $3 / 4$ lateral view; $\mathbf{g}$ flower, lateral view; $\mathbf{h}$ gynostemium, front view (c, d from Batista et al. 1926 (BHCB); e from Batista et al. 2868 (BHCB); f, h from Batista et al. 2838 (BHCB), $\mathbf{g}$ from Batista and Proite 2669 (BHCB)). Photographs by J.A.N. Batista 


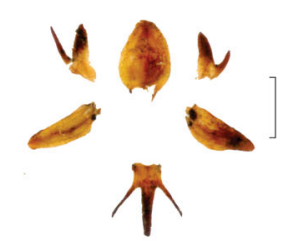

a

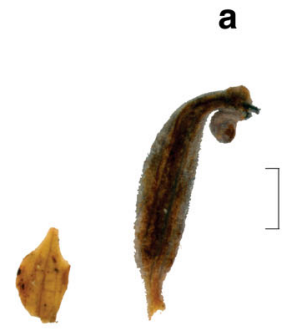

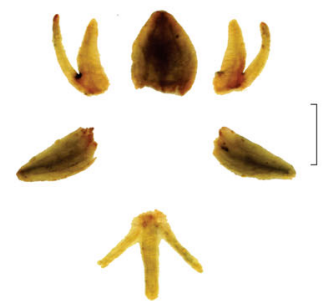

b

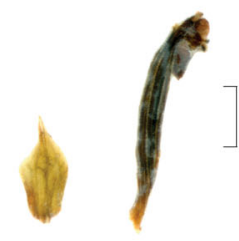

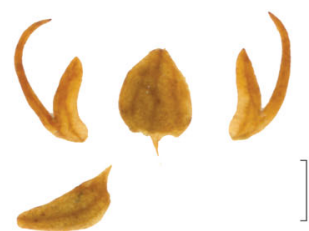

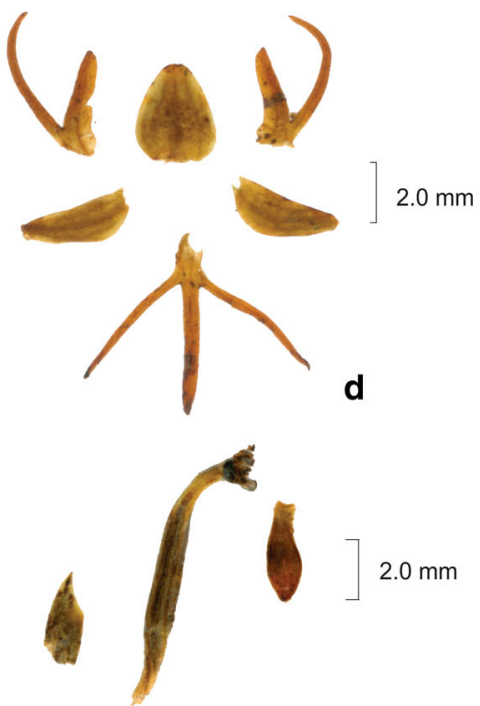

Fig. 9 Habenaria pansarinii var. minuscula: a, b dissected perianth, bract, pedicellate ovary, gynostemium, and spur, lateral view. Habenaria pansarinii: c, d dissected perianth, bract, pedicellate ovary, gynostemium, and spur, lateral view. (a from Batista and

Simões 812 (CEN!, UEC!); São Gonçalo do Rio Preto, Parque Estadual do Rio Preto, próxima a Lapa da Santa, 28 Feb 2008 (fl.), A.J. Ramalho et al. 4 (BHCB!).

Conservation status: The species is known from eight collections from five localities. Populations can be large, but are restricted to very specific habitats and small areas. During all of the collections made by the authors, only a single population was found in a vast area. Only the population in the Rio Preto State Park is located within a protected area. According to the IUCN Red List Categories and Criteria, and guidelines (IUCN 2012, 2016), the species can be tentatively classified as Endangered (EN). The species has small extent of occurrence and area of occupancy estimated in 1623 and $32 \mathrm{~km}^{2}$, respectively, very specific and restricted habitats and five known populations [B1ab(iii) + 2ab(iii); C2a(i)].

Notes: As far as we could determine, H. pansarinii was first collected by Gerdt Hatschbach in 1987 in the municipality of Datas, representing another example of a new species discovered during recent, intensive, botanical surveys in the Espinhaço Range. Habenaria pansarinii is similar to $H$. irwiniana, but distinct by the characters outlined in Table 4. Particularly distinctive are its short (1.9-3.8 $\mathrm{mm}$ long vs. $8-15 \mathrm{~mm}$ long in H. irwiniana) and saccate spurs (vs clavate), which are shorter than the pedicellate ovary (vs about the same size), and geographic distribution (restricted to the Espinhaço Range in Minas Gerais state vs the central highland in Goiás state and the Federal District).

Proite 2669 (BHCB); b from Batista et al. 2838 (BHCB); c from Batista and Proite 2669 (BHCB), d from Batista et al. 2838 (BHCB)). Scale bars $2 \mathrm{~mm}$

Habenaria pansarinii var. minuscula J.A.N.Bat. \& Bianch., var. nov.-TYPE: Brazil, Minas Gerais, Santana do Riacho, Serra do Cipó, MG-010, 12.5 km após a ponte sobre o córrego Soberbo em Cardeal Mota, em direção a Conceição do Mato Dentro, antigo km 112, 19 $17^{\prime} \mathrm{S}$, $43^{\circ} 33^{\prime}$ W, 1284 m a. s. $1 ., 29$ Apr 2008 (fl.), J.A.N. Batista and K. Proite 2669 (holotype: BHCB 120350!; isotypes: CEN, RB, SP) (Figs. 8f, h, 9a, b).

Etymology: From the Latin minusculus (rather less, rather small, very small), diminutive of minus (less), in reference to the size of the flowers, which are smaller than the typical variety.

Similar to $H$. pansarinii, but distinct by having smaller flowers (lateral sepals 2.2-3.1 × 1.0-1.4 mm), shorter lateral segments of the petals and lip (petal anterior segment 1.1-2.5 mm long; lip lateral segments $1.5-2.2 \mathrm{~mm}$ long), shorter spurs (1.2-1.4 mm long), its habitat (permanently wet grasslands not directly associated with rock outcrops), and phenology (flowering at the very end of the rainy season, from March to May).

Terrestrial slender herb. Stem erect, 7-28 cm long, including the inflorescence. Leaves concentrated at the stem base, spreading, linear-lanceolate, $0.8-2.6 \times 0.1-0.4 \mathrm{~cm}$. Inflorescence $0.7-6.0 \mathrm{~cm}$ long, lax, spiral; floral bracts ovate, apiculate, $2.2-3.5 \times 1.2-1.8 \mathrm{~mm}$, shorter than the pedicellate ovary. Flowers 1-8(-12), greenish; pedicellate ovary parallel to the rachis or spreading, $6.7-8.1 \mathrm{~mm}$ long; ovary straight, 5.5-6.2 mm long; pedicel 1.3-1.9 mm long. Sepals green, margins smooth, whitish; dorsal sepal concave, when flattened 
ovate, $2.4-3.0 \times 1.8-2.4 \mathrm{~mm}$; lateral sepals obliquely lanceolate, spreading, 2.2-3.1 × 1.0-1.4 mm. Petals bipartite, base whitish, segments green or greenish yellow; posterior segment lanceolate, 2.1-2.7 × 0.7-0.8 mm, acute, adherent to the dorsal sepal; anterior segment erect, filiform, inserted at the base of the posterior segment, 1.1-2.5 mm long, 0.5-0.9 times as long as the posterior segment. Lip tripartite; undivided basal part short, $0.6-0.7 \times$ 0.9-1.1 mm, whitish; segments green or greenish yellow; lateral segments pendent, linear, 1.5-2.2 mm long, 0.8-0.9 times as long as the median segment; median segment linear, $1.7-2.5 \times 0.4-0.6 \mathrm{~mm}$; spur free from the bracts, saccate, $1.2-1.4 \mathrm{~mm}$ long, $0.1-0.2$ times as long as the pedicellate ovary. Gynostemium erect; connective emarginate, light green; lateral appendages (auricles) fleshy, verrucose, whitish, truncate. Anther bilocular, loculi parallel, canals obscure or absent; hemipollinaria joined by the viscidia. Stigmatophores (stigma lobes) 2, closely parallel, together throughout, green, receptive surface slightly concave, turned frontwards. Rostellum light green; mid-lobe triangular, fleshy, acute, erect, completely placed between the anther loculi; side-lobes convergent towards the apices.

Phenology: Flowering occurs at the very end of the rainy season, from March to early May (Table 3). Flowering of this variety is enhanced by seasonal brush fires, and the two collections made by the authors were from sites that had burned during the dry season. Other species such as Habenaria ayangannensis, $H$. leprieurii, and $H$. nuda Lindl. are sympatric, occur in similar or adjacent habitats, and flower at about the same time.

Habitats: Grows in permanently wet grasslands, with dark, hydromorphic, loamy soils, at 1200-1600 m a. s. 1 .

Distribution: Restricted to the southern and central regions of the Espinhaço Range in Minas Gerais state, from Serra do Caraça in the Iron Quadrangle (Quadrilátero Ferrífero) to the Diamantina plateau.

Additional specimens examined: Brazil. Minas Gerais: Diamantina, Parque Nacional das Sempre Vivas, Campos de São Domingos, próximo à sede do Parque, $17^{\circ} 54^{\prime} \mathrm{S}$, $43^{\circ} 47^{\prime}$ W, $1260 \mathrm{~m}$ a. s. 1., 6 Mar 2009 (fl.), J.A.N. Batista et al. 2838 (BHCB!); Diamantina, estrada para São João da Chapada, a $14 \mathrm{~km}$ do asfalto, $18^{\circ} 09^{\prime} \mathrm{S}, 43^{\circ} 43^{\prime} \mathrm{W}, 11 \mathrm{Apr}$ 1982 (fl.), A. Furlan et al. in CFCR 3358 (SPF!); São Gonçalo do Rio Preto, Parque Estadual do Rio Preto, $18^{\circ} 12^{\prime} 15^{\prime \prime} \mathrm{S}, 43^{\circ} 20^{\prime} 27^{\prime \prime} \mathrm{W}, 1312 \mathrm{~m}$ a. s. 1., 19 Mar 2007 (fl.), N.F.O. Mota 1315 (BHCB!); Catas Altas, Serra do Caraça, trilha que leva ao Pico do Sol, 8 May 2003 (fl.), R.C. Mota 2061 (BHCB!).

Conservation status: This variety is known from five collections from five localities, with small and restricted populations. Two collections made by the authors were from a small, restricted population. Three of the known populations are located inside protected areas. According to the IUCN Red List Categories and Criteria, and guidelines (IUCN 2012, 2016), this taxon can be tentatively classified as Endangered (EN), due to its small area of occupancy estimated in $20 \mathrm{~km}^{2}$, restricted habitats, populations with few individuals, and no more than five known populations [B2ab(iii); C2a(i)].

Notes: This taxon is a recent addition to the flora of the Espinhaço Range and was first collected in 1982 by Antônio Furlan in Diamantina. It is similar in general morphology to $H$. pansarinii, but distinct by having lessdeveloped leaves, smaller flowers, shorter lateral segments of the petals and lip, and shorter spurs. Additionally, it grows in permanently wet grasslands not directly associated with rock outcrops, and flowers at the very end of the rainy season. This variety is sympatric with the typical variety in the Rio Preto State Park and the Sempre Vivas National Park, but their populations occur in different, well-separated habitats, and bloom at different times. As this entity forms morphologically homogeneous populations and has distinctive characteristics that are not found within the range of variation of $H$. pansarinii var. pansarinii, we considered it distinct enough to be recognized as a separate taxon. In defining its taxonomic rank we followed Stace (1989), who defined a variety as 'a population of one or several biotypes, forming more or less distinct local races of a species'.

Habenaria campylogyna J.A.N.Bat. \& Bianch., nom. nov. $\equiv$ Habenaria humilis Cogn., Mart., Fl. Bras. 3(4): 67. 1893. nom. illeg. [Art. 53] (not Habenaria humilis (Michx.) Sw., Adnot. Bot. 47. 1829. 三 Orchis humilis Michx., Fl. Bor. Am. 2: 155. 1803)._TYPE: Brazil, Minas Gerais: Serra do Itabira do Campo, 20 Dec 1888 (fl.), C.A.W. Schwacke 6386 (lectotype designated here: R 28718 barcode R000028718!; isolectotype: SP 32350!); Pico d'Itabira do Campo, 20 Dec 1888 (fl.), A.F.M. Glaziou 17813 (syntypes: K barcode K000363826!, P barcodes P00386906!, P00386907!; RENZ [Web! photocopy, drawing and fragment of the syntype P00386907]) (Figs. 10, 11).

Etymology: From the Greek campylos (bent, curved) and gyne (female), referring to the strongly curved ovary of the species.

Terrestrial slender herb. Tuberoid root ellipsoid, $8-10 \times 2-5 \mathrm{~mm}$. Roots sparsely hairy, $0.7-1.0 \mathrm{~mm}$ wide, whitish. Stem erect, 7-18(-24) cm long including the inflorescence, 0.7-1.0 mm wide. Leaves 3-4(-5), spreading, largest (1-)2-3, at the base of the stem, linear, narrow, 
Fig. 10 Habenaria campylogyna: a habit; b leaf; c flower, $3 / 4$ lateral view; d dissected perianth; e pedicellate ovary, gynostemium, and spur, lateral view; f gynostemium, lateral view; g rostellum, lateral view; h rostellum, upper view. All based on Batista and Proite 1000 (CEN). Drawn by Maria Helena Burian

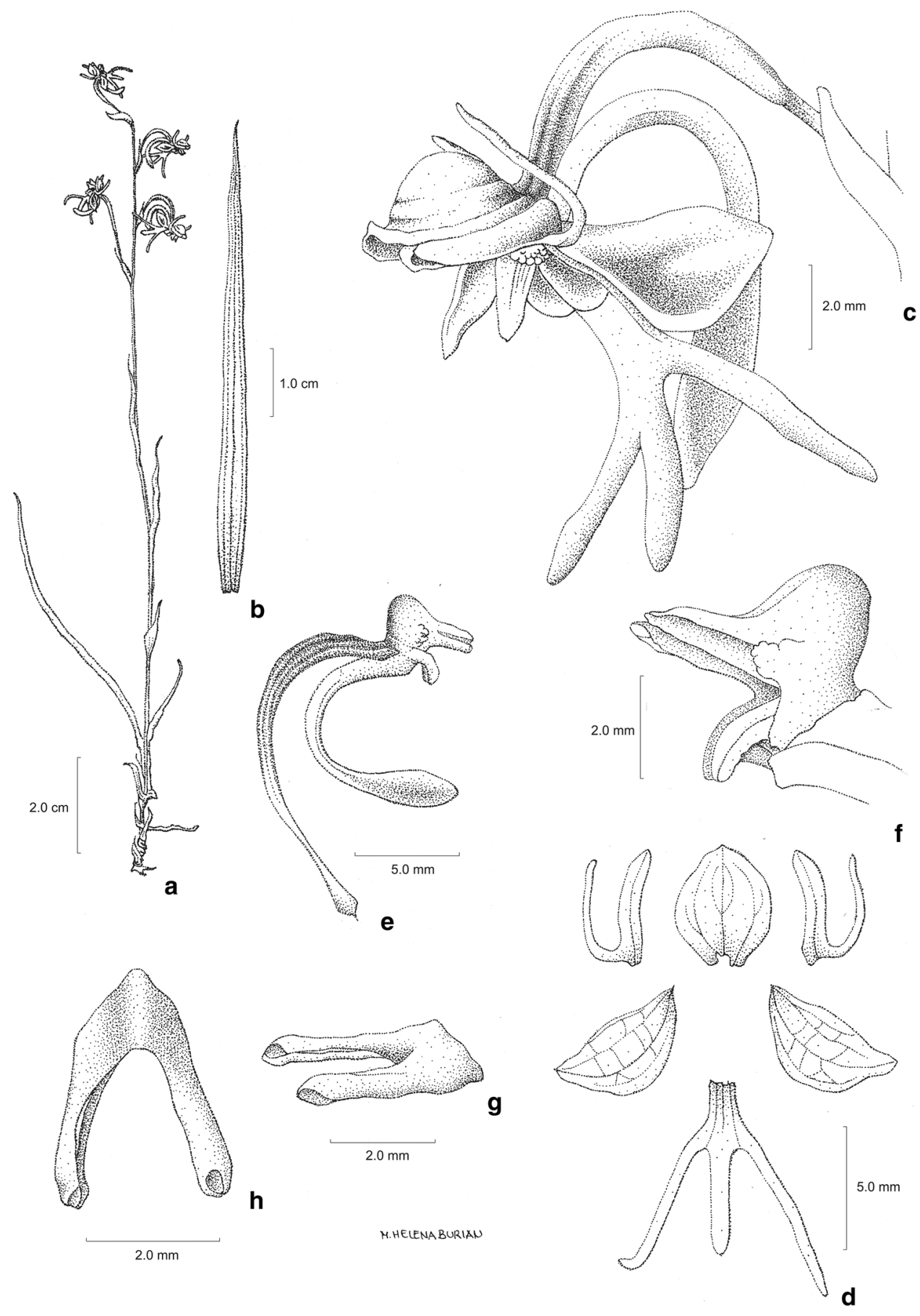

$3.5-10.5 \times 0.2-0.4 \mathrm{~cm}$; bract-like leaves along the stem $1(-2), 0.8-3.5 \mathrm{~cm}$ long. Inflorescence $1.0-9.0 \mathrm{~cm}$ long, few-flowered, lax; floral bracts broadly elliptical to lanceolate, caudate, 3.0-9.0(-19.0) $\times 1.5-4.0 \mathrm{~mm}$, shorter than the pedicellate ovary. Flowers $1-6(-10)$, green; pedicellate ovary ascending to inclined, 13-19 mm long, ovary strongly curved, (7-)9-11 mm long, pedicel 4-7 mm long. Sepals green, mucronate, margins smooth; dorsal sepal strongly concave, when flattened elliptical, 4-6 × 3-5 mm; lateral sepals obliquely elliptical, obtuse or subacute, deflexed, $5.5-7.0 \times 2.5-4.0 \mathrm{~mm}$. Petals bipartite, light green; posterior segment linear-falcate, $4.0-6.0 \times 0.8-1.1 \mathrm{~mm}$, acute, adherent or free from the dorsal sepal; anterior segment erect, reflexed, linear-filiform, inserted at the base of the posterior segment, 3.5-4.0(-6.0) $\mathrm{mm}$ long, shorter or about the same size as the posterior segment. Lip tripartite, green; undivided basal part prominent, $1.5-3.0 \times 1.3-1.8 \mathrm{~mm}$; lateral segments reflexed, linear-filiform, 6-8 $\mathrm{mm}$ long, longer than the median segment; median segment linear, 4.0-5.0(- 

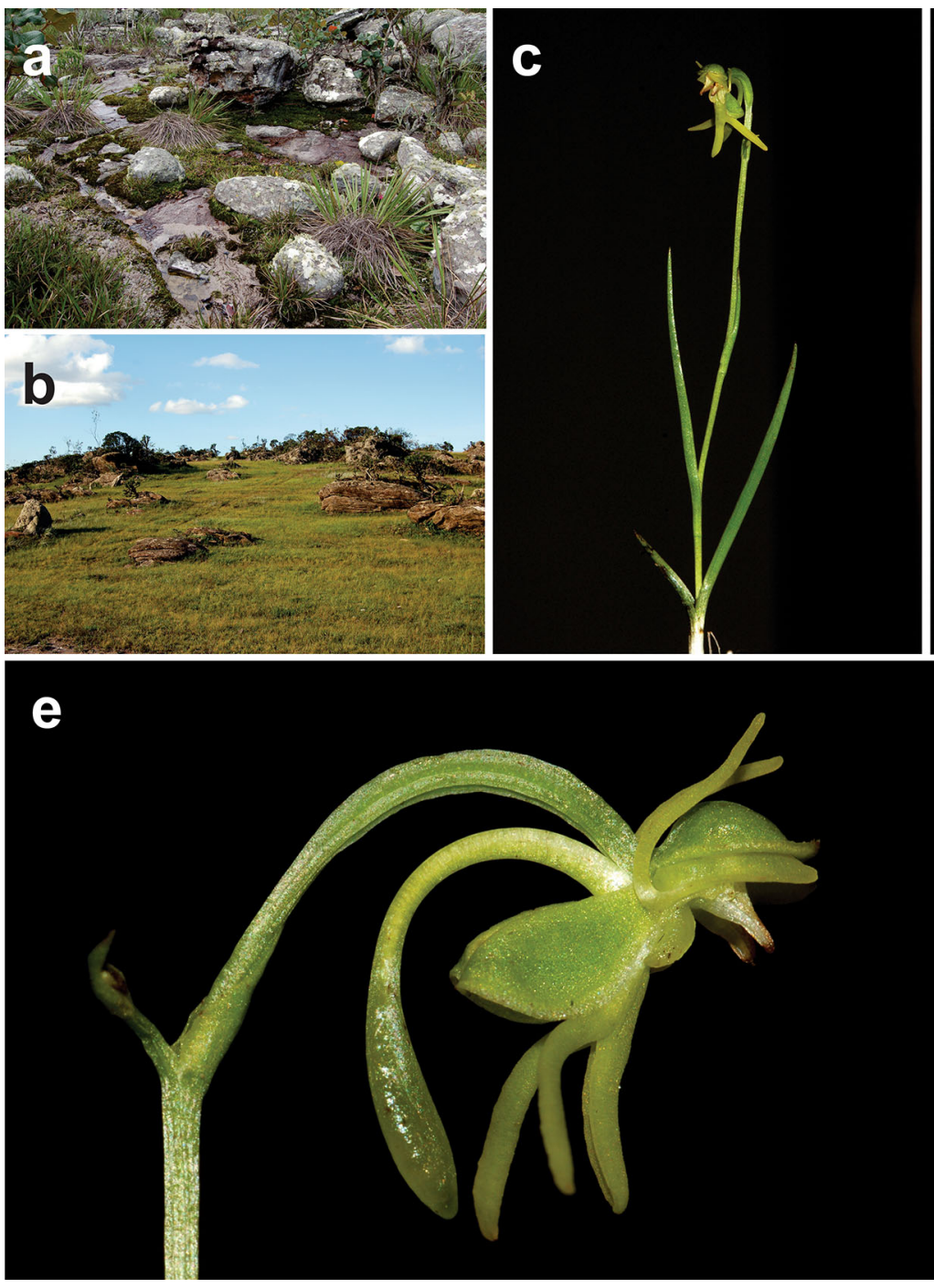
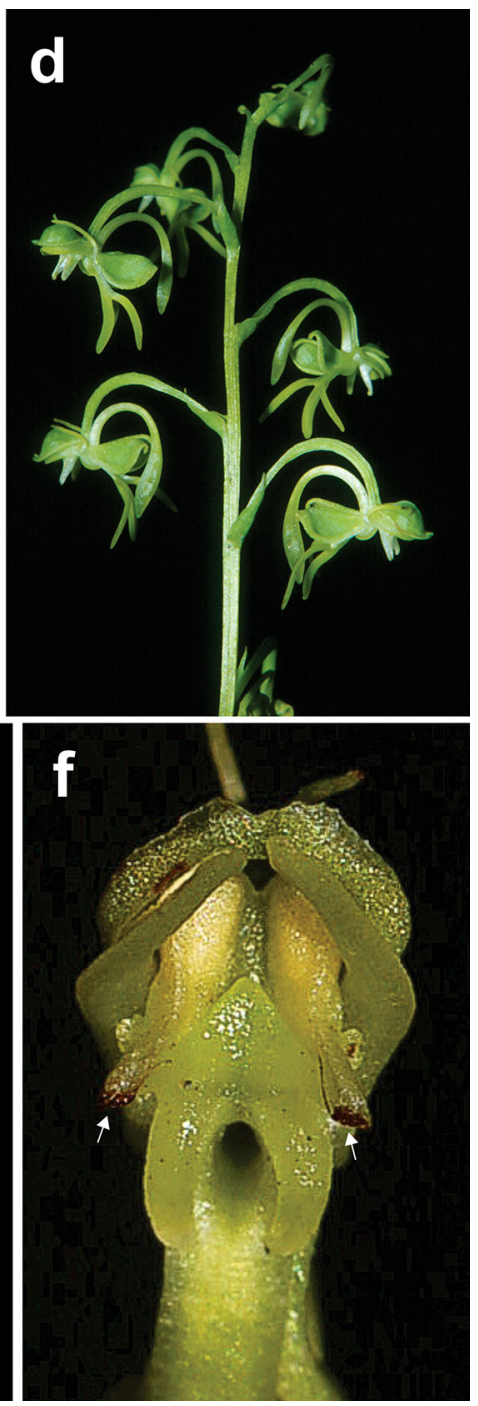

Fig. 11 Habenaria campylogyna a habitat, campo rupestre (Sempre Vivas National Park, Diamantina, Minas Gerais state; March/2009); b habitat, seasonally humid grassland associated with quartzite outcrops (summit of Serra do Ouro Branco, Minas Gerais state, March/2008); c plant; d inflorescence; e flower, lateral view;

$6.0) \times 0.8-1.0(-1.5) \mathrm{mm}$; spur strongly curved, free from the bracts, clavate, shorter than the pedicellate ovary, $10-13 \mathrm{~mm}$ long, base $0.5-0.8 \mathrm{~mm}$ wide, apex $1.0-1.5 \mathrm{~mm}$ wide, green. Gynostemium erect, $2.0-2.5 \mathrm{~mm}$ high; connective emarginate, green; lateral appendages (auricles) fleshy, verrucose, whitish, $0.5-1.3 \times 0.5 \mathrm{~mm}$. Anther bilocular, loculi parallel, $1.3-1.5 \mathrm{~mm}$ high, canals prominent, $1.8-2.5 \mathrm{~mm}$ long; hemipollinaria separate; viscidia positioned in the internal side of the rostellum arms, turned downwards, $0.3-0.5 \times 0.2-0.3 \mathrm{~mm}$, spaced $1.5-2.0 \mathrm{~mm}$ from each other; caudicles $1.7-2.3 \mathrm{~mm}$ long. Stigmatophores (stigma lobes) 2, parallel to slightly divergent, separate, linear, 2.3-2.5 mm long, green, receptive surface curved, $1.9 \times 0.5 \mathrm{~mm}$, obtuse. Rostellum $3.2-4.0 \mathrm{~mm}$ f gynostemium, front view, position of the viscidia are indicated by arrows (c, e from Batista et al. 2729 (BHCB); d from Batista and Proite 1000 (CEN); f from Batista et al. 2738 (BHCB)). Photographs by J.A.N. Batista

long, green, mid-lobe triangular, fleshy, obtuse, erect, completely placed between the anther loculi, $0.9-1.5 \mathrm{~mm}$ long, $0.9-1 \mathrm{~mm}$ high, side-lobes parallel at base, slightly divergent towards the apices, $2.5 \mathrm{~mm}$ long.

Phenology: Flowering occurs from December to March, but is most concentrated during January and February at the peak of the rainy season (Table 3). Although most of the collections made by the authors were from areas that had burned during the previous dry season, some were made in non-burned areas, indicating that flowering of this species may be less influenced by fire than in other Habenaria species and terrestrial orchids that grow in open grasslands. 
Habitats: Habenaria campylogyna grows in seasonally humid grasslands, usually associated with campo rupestre (rocky field) vegetation, in dark, shallow, rocky, sandyclay soils, at 1200-1600 m a.s.l. The soil becomes superficially humid during the rainy season but usually completely dries during the dry season. Other orchid species such as Habenaria alpestris, $H$. balansae, $H$. caldensis, $H$. guilleminii, Cleistes exilis Hoehne, C. tenuis (Rchb.f. ex Griseb.) Schltr., Gomesa barbaceniae (Lindl.) M.W.Chase \& N.H.Williams, and Platythelys paranaensis (Kraenzl.) Garay are sympatric, occurring in similar or adjacent habitats, and flower at about the same time.

Distribution area: Restricted to the southern and central regions of the Espinhaço Range in Minas Gerais state, from Serra do Ouro Branco to the Diamantina plateau and São Gonçalo do Rio Preto. The collection Hoehne s.n. (SP 5024) from Serra do Caraça, collected and identified as $H$. humilis by Hoehne (1940), was misidentified; this material belongs to a yet unidentified species, apparently related to H. repens. The report for Goiás state (Pabst and Dungs $1975)$ is based on the misidentification of $H$. irwiniana as H. humilis. The report of $H$. humilis from Santa Catarina state (Pabst and Dungs 1975) is probably a mistake, and the material we examined from that state (Rohr 2336, HB 4771), which was identified by Pabst as H. humilis, is actually $H$. aff. repens. The report for Bahia (Harley and Simmons 1986) is based on the collection Harley et al. 21013, which is $H$. aff. melanopoda. Barros et al. (2016) recorded the species for states of Rondônia and Paraná, although this is probably an error as the specimens were collected quite distant from the known distribution range of the species. A specimen from Paraná identified as $H$. humilis (Von Linsingen and Sonehara 578, ESA) is actually H. schwackei Barb.Rodr.

Additional specimens examined: Brazil. Minas Gerais: Serra do Cipó, $7 \mathrm{~km}$ NE from Cardeal Mota, towards Conceição do Mato Dentro, 8 Feb 1991 (fl.), Arbo et al. 4638 (AMES!); Santana do Riacho, Serra do Cipó, Parque Nacional da Serra do Cipó, 1 Feb 1987 (fl.), F. Barros 1300 (SP!); F. Barros 1316 (SP!); Serra do Cipó, MG-10, km 112 on the road towards Conceição do Mato Dentro, about $11 \mathrm{~km}$ NE from Cardeal Mota, 9 Jan 2000 (fl.), J.A.N. Batista and K. Proite 1000 (CEN!); Nova Lima, Morro do Chapéu, cerca de $18 \mathrm{~km} \mathrm{~S}$ de Belo Horizonte, $20^{\circ} 6^{\prime} 47^{\prime \prime} \mathrm{S}$, $43^{\circ} 54^{\prime} 42.4^{\prime \prime} \mathrm{W}, 1405 \mathrm{~m}$ a. s. 1., 20 Jan 2007 (fl.), J.A.N. Batista et al. 1901 (BHCB!); Ouro Branco, Serra do Ouro Branco, cerca de $10.6 \mathrm{~km}$ do entroncamento com a MG443 , cume da serra, $20^{\circ} 29^{\prime} 11.2^{\prime \prime} \mathrm{S}, 43^{\circ} 42^{\prime} 37^{\prime \prime} \mathrm{W}, 1529 \mathrm{~m}$ a. s. 1., 5 Mar 2008 (fl., fr.), J.A.N. Batista 2619 (BHCB!); Moeda, Serra da Moeda, entrada para Moeda, cerca de $33 \mathrm{~km} \mathrm{~S}$ de Belo Horizonte a partir do entroncamento do anel rodoviário com a BR-040, cerca de $3 \mathrm{~km}$ após o entroncamento com a BR-041, 20 $10^{\prime} 45.5^{\prime \prime} \mathrm{S}$, $43^{\circ} 56^{\prime} 58.5^{\prime \prime} \mathrm{W}, 1333 \mathrm{~m}$ a. s. 1., 19 Jan 2009 (fl.), J.A.N. Batista et al. 2729 (BHCB!); Brumadinho, Retiro das

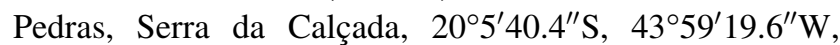
1376 m a. s. 1., 21 Jan 2009 (fl.), J.A.N. Batista et al. 2738 (BHCB!); Diamantina, Parque Nacional das Sempre Vivas, Campos de São Domingos, $17^{\circ} 54^{\prime} 26^{\prime \prime} \mathrm{S}, 43^{\circ} 47^{\prime} 4.4^{\prime \prime} \mathrm{W}$, 1288 m a. s. 1., 7 Mar 2009 (fl., fr.), J.A.N. Batista et al. 2852 (BHCB!); Diamantina, estrada entre Macacos e São João da Chapada, $18^{\circ} 2^{\prime} 3.3^{\prime \prime} \mathrm{S}, 43^{\circ} 47^{\prime} 20.1^{\prime \prime} \mathrm{W}, 1295 \mathrm{~m}$ a. s. 1., 8 Mar 2009 (fl.), J.A.N. Batista et al. 2875 (BHCB!); Santana do Riacho, Parque Nacional da Serra do Cipó, região de Congonhas, 3 Feb 1994 (fl.), E.L. Borba 106 (BHCB!); Moeda, Marinho da Serra, 20 $19^{\prime} 28^{\prime \prime} \mathrm{S}$, $43^{\circ} 56^{\prime} 24^{\prime \prime} \mathrm{W}, 1450 \mathrm{~m}$ a. s. 1., 20 Jan 2009 (fl.), F.F. Carmo 4022 (BHCB!); Brumadinho, Parque Estadual Serra do

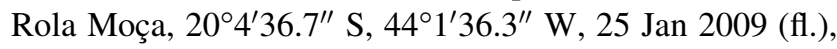
F.F. Carmo 4125 (BHCB!); [Itabirito], Pico de Itabira do Campo, L. Damasio s.n. (OUPR 9710!); Jaboticatubas, Serra da Lagoa Dourada, 12 Feb 1996 (fl.), R.C. Forzza et al. 163 (SPF!); Moeda, Serra da Moeda, 5 Jan 1990 (fl.), T.S.M. Grandi and L.M. Porto de Paula 1089BHZB!); Serra do Cipó, 6 Mar 1958 (fl.), E.P. Heringer 6218 (HB!); Serra do Itabirito, $45 \mathrm{~km}$ SE of Belo Horizonte, 1,600 m a. s. 1., 12 Feb 1968 (fl.), H.S. Irwin et al. 19884 (HB!, IAN!, M!, NY!, RB!, UB!); Serra do Cipó, km 120, 1200 m a. s. 1., 14 Feb 1968 (fl.), H.S. Irwin et al. 20066 (AMES!, HB!, NY!, RB!, UB!); Moeda, Serra da Moeda, $20^{\circ} 17^{\prime} \mathrm{S}$, $43^{\circ}$ 57’W, 10 Feb 1999 (fl.), J.A. Lombardi 2477 (BHCB!, mixed with $H$. secundiflora); São Gonçalo do Rio Preto, Parque Estadual do Rio Preto, Chapada do Couto, próximo ao córrego da Garrincha em direção ao Pico Dois Irmãos, $18^{\circ} 13^{\prime} 53^{\prime \prime} \mathrm{S}, 43^{\circ} 19^{\prime} 44^{\prime \prime} \mathrm{W}, 1420 \mathrm{~m}$ a. s. 1., 18 Jan 2011 (fl.), N.F.O. Mota 2051 (BHCB!); Santana do Riacho, Parque Nacional da Serra do Cipó, Dec 2007 (fl.), A.C.D. Munhoz et al. 77 (BHCB!); Santana do Riacho, Parque Nacional da Serra do Cipó, 13 Feb 2008 (fl.), A.C.D. Munhoz and C.A.N. Martins 100 (BHCB!); Itabira, Parque Nacional da Serra do Cipó, $19^{\circ} 23^{\prime} 17^{\prime \prime} \mathrm{S}, 43^{\circ} 33^{\prime} 30^{\prime \prime} \mathrm{W}, 1,318 \mathrm{~m}$ a. s. 1 ., 21 Mar 2008, A.C.D. Munhoz et al. 177 (BHCB!); A.C.D. Munhoz et al. 178 (BHCB!); Serra do Cipó, 2 Mar 1997 (fl.), R.S. Oliveira 278 (CEN!, UB!); Diamantina, estrada para Conselheiro Mata, 8-9 km após a entrada desta estrada na BR 259, $18^{\circ} 17^{\prime} 32^{\prime \prime} \mathrm{S}, 43^{\circ} 44^{\prime} 18^{\prime \prime} \mathrm{W}, 13$ Feb 2007(fl.), P.L. Ribeiro et al. 224A (HUEFS 119726!, mixed with Habenaria sp.); Jaboticatubas, km 114 on the road from Lagoa Santa to Conceição do Mato Dentro, 10 Dec 1971 (fl.), M. Sazima 13367 (UEC!); Jaboticatubas, km 121 on the road from Lagoa Santa to Conceição do Mato Dentro, 8 Feb 1972 (fl.), M. Sazima 13403 (UEC!); Serra do Cipó, Jaboticatubas, 5 Jan 1973 (fl.), J. Semir and A.B. Joly 3722 (SP!); Itabirito, Pico do Itabirito, 18 Jan 1994 (fl.), W.A. Teixeira s.n. (BHCB 26090!); Diamantina, 
Macacos, entre São João da Chapada e Macacos, $9 \mathrm{~km}$ de Macacos, $18^{\circ} 2^{\prime} 14^{\prime \prime} \mathrm{S}, 43^{\circ} 47^{\prime} 20^{\prime \prime} \mathrm{W}, 20$ Feb 2012 (fl.), $1280 \mathrm{~m}$ a. s. 1., A.A. Vale and V.A.O. Dittrich 76 (BHCB!); Diamantina, Olhos D'Água, Parque Nacional das Sempre Vivas, estrada para Campo Triste, próximo ao Renegado, aprox. $15 \mathrm{~km}$ da casa do pesquisador, $17^{\circ} 50^{\prime} 21^{\prime \prime} \mathrm{S}$, $43^{\circ} 45^{\prime} 56^{\prime \prime} \mathrm{W}, 1250 \mathrm{~m}$ a. s. 1., 21 Feb 2012 (fl.), A.A. Vale and V.A.O. Dittrich 95 (BHCB!); Serro, Capivari, estrada para o Pico do Itambé, aprox. 3,5 km de Capivari, 23 Feb 2012 (fl.), A.A. Vale and V.A.O. Dittrich 110 (BHCB!); Serra do Cipó, 4 Feb 1980 (fl.), G. Windisch 2593 (HB!, M!); Conceição do Mato Dentro, estrada na APA do Intendente, $19^{\circ} 8^{\prime} 37^{\prime \prime} \mathrm{S}, 43^{\circ} 33^{\prime} 11^{\prime \prime} \mathrm{W}, 1355 \mathrm{~m}$ a. s. $1 ., 19$ Feb 2004 (fl.), C. van den Berg 1355 (HUEFS!).

Conservation status: According to the IUCN Red List Categories and Criteria, and guidelines (IUCN 2012, 2016), this species could be classified as Endangered (EN), due to its small area of occupancy estimated in $84 \mathrm{~km}^{2}$. However, because the species is known from about 10 localities and occasionally forms large populations, some of which occur within federal or state protected areas, we tentatively classify it as Vulnerable (VU), due to its restricted and specific habitats, and extent of occurrence estimated in 12,077 $\mathrm{km}^{2}$ [B1ab(iii) + 2ab(iii); C2a(i)].

Illustrations: Hoehne (1940; table 117; Fig. 2, as $H$. humilis), based on the collection Schwacke 6386 (R 28718). The illustration of $H$. humilis provided by Pabst and Dungs (1975, p. 255, Figure 151) is H. irwiniana.

Notes: The name Habenaria humilis (Michx.) Sw. was used before in the genus by Swartz for the species now known as Galearis spectabilis (L.) Raf.; therefore, $H$. humilis Cogn. is a latter homonym and an illegitimate name. A new name, $H$. campylogyna, is proposed here for the species.

Among New World Habenaria, H. campylogyna is a very distinct species, and its morphological affinities are still unclear. In terms of its habit, $H$. campylogyna is similar to the other species described in this work $(H$. brachydactyla, $H$. irwiniana, $H$. minuta, and $H$. pansarinii), being characterized as slender plants with linear, basal leaves. However, they differ in terms of the morphologies of the perianth and gynostemium (Table 4), ecological preferences, and distributions. The distinctive features of H. campylogyna are its strongly curved ovaries and spurs, prominent anther canals, slightly divergent, $1.8-2.5 \mathrm{~mm}$ long, and the separate stigmatophores. In terms of the general morphology of the flower, $H$. campylogyna is surprisingly similar to $H$. reflexa Blume, from Java, Sumatra, Peninsular Malaysia, Thailand, and Sikkim (Seidenfaden 1977; Comber 1990). Similar characters are the curved spur and the long anther canals and rostellum arms-suggesting similar pollination mechanisms for both species. Habenaria reflexa plants, however, are taller (about $50 \mathrm{~cm}$ tall), with leaves larger (ca. $18 \times 5.5 \mathrm{~cm}$ ) and lanceolate, petals simple, lip mid-lobe ca. $16 \mathrm{~mm}$ long, and they grow in forest habitats (Comber 1990). The strongly curved ovary and spur of $H$. campylogyna are uncommon among New World Habenaria. Specimens of $H$. balansae sometimes also present these same characters, although the leaves of that species are spread along the stem, the flowers are smaller, and the viscidia united.

A distinctive feature of $H$. campylogyna is the position of its viscidia. In all of the New World Habenaria species with prominent and protruding anther canals that we have examined, the viscidia have a terminal position at the end of the rostellum side-lobes, facing forward and outward. The viscidia of $H$. campylogyna are also placed at the apex, but on the internal sides of the rostellum side-lobes and turned downwards, implying that the pollinator must approach the flower from below.

Acknowledgements The authors thank the curators and staff of the AMES, BHCB, BHZB, CEN, ESA, G, HB, HBG, HEPH, HUEFS, IAN, K, M, MBM, NY, OUPR, P, R, RB, RENZ, S, SP, SPF, UB, UEC, and UFG herbaria for the loans of material, images, or for providing access to their collections; Instituto Estadual de Florestas de Minas Gerais (IEF MG) and Instituto Chico Mendes de Conservação da Biodiversidade (ICMBio) for the scientific collection permits; Maria Helena Burian for the line drawings; Roy Funch for revising the English of the manuscript; two anonymous reviewers and handling editor Ricarda Riina for helpful comments and corrections that improved the manuscript; Fundação Grupo Boticário de Proteção à Natureza, Fundação de Amparo à Pesquisa do Estado de Minas Gerais (FAPEMIG), and Conselho Nacional de Desenvolvimento Científico e Tecnológico ( $\mathrm{CNPq})$ for financial support. JANB also acknowledge a scholarship received from $\mathrm{CNPq}(\mathrm{Pq}-2)$.

Funding This study was funded by Fundação Grupo Boticário de Proteção à Natureza (Grant Number 0702_2006-1), Fundação de Amparo à Pesquisa do Estado de Minas Gerais-FAPEMIG (Grant Number CRA APQ-4871-5.02/07)—and Conselho Nacional de Desenvolvimento Científico e Tecnológico-CNPq (Grant Number 484564/2006-4).

\section{Compliance with ethical standards}

Conflict of interest The authors declare that they have no conflict of interest.

Employment João A. N. Batista is a employee of Universidade Federal de Minas Gerais and Luciano B. Bianchetti is a employee of Empresa Brasileira de Pesquisa Agropecuária.

\section{References}

Bachman S, Moat J, Hill AW, de la Torre J, Scott B (2011) Supporting Red List threat assessments with GeoCAT: geospatial conservation assessment tool. ZooKeys 150:117-126. doi:10. 3897/zookeys.150.2109 
Barros F,Vinhos F, Rodrigues VT, Barberena FFVA, Fraga CN, Pessoa EM, Forster W, Menini Neto L, Furtado SG, Nardy C, Azevedo CO, Guimarães LRS (2016) Orchidaceae in Lista de Espécies da Flora do Brasil. Jardim Botânico do Rio de Janeiro. Available at: http://floradobrasil.jbrj.gov.br/jabot/floradobrasil/ FB20069/. Accessed 15 June 2016

Batista JAN, Bianchetti LB (2003) Lista atualizada das Orchidaceae do Distrito Federal. Acta Bot Brasil 17:183-201. doi:10.1590/ S0102-33062003000200003

Batista JAN, Bianchetti LB, Nogueira RE, Pellizzaro KF, Ferreira FE (2004) The genus Habenaria (Orchidaceae) in the Itacolomi State Park, Minas Gerais, Brazil. Sitientibus Sér Ci Biol 4:25-36

Batista JAN, Bianchetti LB, González-Tamayo R, Figueroa XMC, Cribb PJ (2011a) A synopsis of new world Habenaria (Orchidaceae) I. Harvard Pap Bot 16:1-47. doi:10.3100/025.016.0101

Batista JAN, Bianchetti LB, González-Tamayo R, Figueroa XMC, Cribb PJ (2011b) A synopsis of new world Habenaria (Orchidaceae) II. Harvard Pap Bot 16:233-273. doi:10.3100/0.25.016.0202

Batista JAN, Menini Neto L, Vale AA (2012) Three new species, four new records and an updated checklist of Habenaria (Orchidaceae) from Rio Grande do Sul, Brazil. Nordic J Bot 30:277-290. doi:10.1111/j.1756-1051.2012.01349.x

Batista JAN, Borges KS, Faria MW, Proite K, Ramalho AJ, Salazar GA, van den Berg C (2013) Molecular phylogenetics of the species-rich genus Habenaria (Orchidaceae) in the New World based on nuclear and plastid DNA sequences. Molec Phylogen Evol 67:95-109. doi:10.1016/j.ympev.2013.01.008

Batista JAN, Proite K, Carvalho BM, Vale AA, Felix LP (2014) From Cuba to most of the Neotropic: habenaria Bicornis (Orchidaceae) is widespread from Mexico to Southeastern Brazil. Lankesteriana 13:165-184

Batista JAN, Vale AA, Carvalho BM, Proite K, Ramalho AJ, Munhoz ACD, van den Berg C, Bianchetti LB (2016) Four new species in Habenaria (Orchidaceae) from the Espinhaço Range, Brazil. Syst Bot 41:275-292. doi:10.1600/036364416X691876

Bianchetti LB, Batista JAN, Pellizaro KF, Augusto MM (2006) Família Orchidaceae na APA de Cafuringa. In: Netto PB, Mecenas VV, Cardoso ES (eds) APA de Cafuringa a última fronteira natural do DF. Secretaria de Meio Ambiente e Recursos Hídricos, Brasília, pp 153-163

Bonfield JK, Smith KF, Staden R (1995) A new DNA sequence assembly program. Nucl Acids Res 23:4992-4999. doi:10.1093/ nar/23.24.4992

Bouetard A, Lefeuvre P, Gigant R, Bory S, Pignal M, Besse P, Grisoni M (2010) Evidence of transoceanic dispersion of the genus Vanilla based on plastid DNA phylogenetic analysis. Molec Phylogen Evol 55:621-630. doi:10.1016/j.ympev.2010. 01.021

Cameron KM (2005) Leave it to the leaves: a molecular phylogenetic study of Malaxideae (Epidendroideae, Orchidaceae). Amer J Bot 92:1025-1032. doi:10.3732/ajb.92.6.1025

Carnevali G, Carnevali IR (1993) New or noteworthy orchids for the Venezuelan Flora IX: new taxa, new records, and nomenclatural changes, mainly from the Guayana Shield and Northern Amazonas. Novon 3:102-125

Carnevali G, Ramírez I (1985) Orchidaceae nuevas o interesantes para la Flora de Venezuela (II). Habenaria guanchezii Carnevali et Ramírez, nueva especie de la Amazonia Venezolana. Ernstia 33:14-20

Carvalho BM, Ramalho AJ, Batista JAN (2013) O gênero Habenaria (Orchidaceae) na Serra da Canastra, Minas Gerais, Brasil. Rodriguésia 64:223-245. doi:10.1590/S217578602013000200003

Cogniaux A (1893) Orchidaceae. Habenaria. In: Martius CFP, Eichler AG, Urban I (eds) Flora Brasiliensis 3(4). F. Fleischer, München, pp 18-102
Comber JB (1990) Orchids of java. Royal Botanic Gardens, Kew

Edgar RC (2004) MUSCLE: multiple sequence alignment with high accuracy and high throughput. Nucl Acids Res 32:1792-1797. doi:10.1093/nar/gkh340

Erixon P, Svennblad B, Britton T, Oxelman B (2003) Reliability of Bayesian posterior probabilities and bootstrap frequencies in phylogenetics. Syst Biol 52:665-673. doi:10.1080/10635150390235485

Felsenstein J (1985) Confidence limits on phylogenies: an approach using the bootstrap. Evolution (Lancaster) 39:783-791

Fitch WM (1971) Toward defining the course of evolution: minimum change for a specific tree topology. Syst Zool 20:406-416. doi:10.1093/sysbio/20.4.406

Govaerts R, Bernet P, Kratochvil K, Gerlach G, Carr G, Alrich P, Pridgeon AM, Pfahl J, Campacci MA, Baptista DH, Tigges H, Shaw J, Cribb P, George A, Kreuz K, Wood J (2016) World checklist of Orchidaceae. Richmond, U.K. The Board of Trustees of the Royal Botanic Gardens, Kew. Available at: http://apps.kew.org/wcsp/. Accessed 14 June 2016

Harley RM, Simmons NA (1986) Florula of Mucugê: Chapada Diamantina-Bahia. Royal Botanic Gardens, London

Hoehne FC (1940) Orchidaceas, Habenaria. In: Hoehne FC (ed) Flora Brasilica 12(1). Secretaria da Agricultura, Indústria e Comércio de São Paulo, São Paulo, pp 52-254

Inda LA, Pimentel M, Chase MW (2012) Phylogenetics of tribe Orchideae (Orchidaceae: Orchidoideae) based on combined DNA matrices: inferences regarding timing of diversification and evolution of pollination syndromes. Ann Bot (Oxford) 110:71-90. doi:10.1093/aob/mcs083

IUCN (2012) IUCN Red List Categories and Criteria: Version 3.1. Second edition. Gland, Switzerland and Cambridge, UK. Available at: http://www.iucnredlist.org/technical-documents/cate gories-and-criteria

IUCN (2016) Guidelines for using the IUCN red list categories and criteria. Version 12. Prepared by the standards and petitions subcommittee. IUCN Species Survival Commission. IUCN, Gland, Switzerland and Cambridge, UK. Available at: http:// www.iucnredlist.org/documents/RedListGuidelines.pdf

Kränzlin F (1892) Beiträge zu einer monographie der gattung Habenaria Willd. Bot Jahrb Syst 16:52-223

Kränzlin F (1901) Orchidacearum genera et species. Habenaria, vol 1. Mayer and Müller, Berlin

Kress WJ, Prince LM, Williams KJ (2002) The phylogeny and a new classification of the gingers (Zingiberaceae): evidence from molecular data. Amer J Bot 89:1682-1696. doi:10.3732/ajb.89. 10.1682

Linder HP, Kurzweil H (1999) Orchids of Southern Africa. Balkema Publishers, Rotterdam

Miller MA, Pfeiffer W, Schwartz T (2010) Creating the CIPRES Science Gateway for inference of large phylogenetic trees. In: Proceedings of the gateway computing environments workshop (GCE), New Orleans, pp 1-8

Monteiro SHN, Selbach-Schnadelbach A, Oliveira RP, van den Berg C (2010) Molecular phylogenetics of Galeandra (Orchidaceae: Catasetinae) based on plastid and nuclear DNA sequences. Syst Bot 35:476-486. doi:10.1600/036364410792495944

Munhoz ACD (2007) Florística e sistemática do gênero Habenaria (Orchidaceae) na Serra do Cipó. MSc Thesis, Universidade Federal de Minas Gerais, Belo Horizonte, Minas Gerais

Munhoz CBR, Proença CEB (1998) Composição florística do município de Alto Paraíso de Goiás na Chapada dos Veadeiros. Bol Herb Ezechias Paulo Heringer 3:102-150

Nylander JAA (2004) MrModeltest v2. Program distributed by the author. Evolutionary Biology Centre, Uppsala University, Uppsala

Pabst GFJ, Dungs F (1975) Orchidaceae Brasilienses, vol 1. BrückeVerlag Kurt Schmersow, Hildesheim 
Pedron M, Buzatto CR, Ramalho AJ, Carvalho BM, Radins JA, Singer RB, Batista JAN (2014) Molecular phylogenetics and taxonomic revision of Habenaria section Pentadactylae (Orchidaceae, Orchidinae). Bot J Linn Soc 175:47-73. doi:10.1111/boj. 12161

Pridgeon AM, Cribb PJ, Chase MW, Rasmussen FN (2001a) Genera Orchidacearum vol 2, Orchidoideae, part 1. Oxford University Press Inc, New York

Pridgeon AM, Solano R, Chase MW (2001b) Phylogenetic relationships in Pleurothallidinae (Orchidaceae): combined evidence from nuclear and plastid DNA sequences. Amer $\mathrm{J}$ Bot 88:2286-2308

Ronquist F, Huelsenbeck JP, van der Mark P (2005) MrBayes: Bayesian inference of phylogeny. Program distributed by the authors. Available at: http://mrbayes.sourceforge.net/index.php

Russell A, Samuel R, Rupp B, Barfuss MHJ, Šafran M, Besendorfer V, Chase MW (2010) Phylogenetics and cytology of a pantropical orchid genus Polystachya (Polystachyinae, Vandeae, Orchidaceae): evidence from plastid DNA sequence data. Taxon 59:389-404

Schweinfurth C, Schultes RE (1954) A new dwarf Habenaria from Amazonian Colombia. Amer Orchid Soc Bull 23:820-822

Seidenfaden G (1977) Orchid genera in Thailand V. Orchidoideae. Dansk Bot Ark 31:1-148

Simpson MG (2006) Plant systematics. Elsevier Academic Press, Burlington, San Diego and London
Smidt EC, Borba EL, Gravendeel B, Fischer GA, van den Berg C (2011) Molecular phylogeny of the neotropical sections of Bulbophyllum (Orchidaceae) using nuclear and plastid spacers. Taxon 60:1050-1064

Stace CA (1989) Plant taxonomy and biosystematics, 2nd edn. Edward Arnold, Hodder and Stoughton Limited, London

Stamatakis A (2014) RAxML Version 8: a tool for phylogenetic analysis and post-analysis of large phylogenies. Bioinformatics 30:1312-1313. doi:10.1093/bioinformatics/btu033

Stamatakis A, Hoover P, Rougemont J (2008) A rapid bootstrap algorithm for the RAxML web-servers. Syst Biol 75:758-771. doi:10.1080/10635150802429642

Stearn WT (1992) Botanical latin, 4th edn. Timber Press, Portland

Swofford DL (2002) PAUP* Phylogenetic analysis using parsimony (*and other methods). Version 4. Sinauer Associates, Sunderland

Tamura K, Dudley J, Nei M, Kumar S (2007) MEGA4: molecular evolutionary genetics analysis (MEGA) software version 4.0. Molec Biol Evol 24:1596-1599. doi:10.1093/molbev/msm092

Thiers B (2015) [continuously updated] Index herbariorum: a global directory of public herbaria and associated staff. New York Botanical Garden's Virtual Herbarium. Available at: http:// sweetgum.nybg.org/science/ih/. Accessed 30 July 2015

Williams NH, Chase MW, Whitten WM (2001) Phylogenetic positions of Miltoniopsis, Caucaea, a new genus Cyrtochloides, and Oncidum phymatochilum (Orchidaceae: Oncidiinae) based on nuclear and plastid DNA data. Lindleyana 16:272-285 